Yönetim, Ekonomi, Edebiyat, İslami ve Politik Bilimler Dergisi,4(1): 100130, 30 Haziran-June, 2019
JOMELIPS - Journal of Management

Economics Literature Islamic and

Political Sciences

e-ISSN :2547-9512

\title{
Küreselleşmenin Türkiye Sigorta Sektöründeki Etkileri: Şirketlerin Ortaklık Yapısı Ve Pazar Payları
}

\author{
Doktora Ercan Özgül \\ İstanbul Medipol Üniversitesi, Sosyal Bilimler Enstitüsü \\ ercanozguldr@gmail.com \\ Doktora Fahrettin Özdemirci \\ İstanbul Medipol Üniversitesi, Sosyal Bilimler Enstitüsü \\ fahrettin.ozdemirci@gmail.com \\ Doktora Tolga Yazıcı \\ İstanbul Medipol Üniversitesi, Sosyal Bilimler Enstitüsü \\ tolgayazi@hotmail.com \\ Dr. Öğr. Üyesi Elif Baykal* \\ İstanbul Medipol Üniversitesi, İşletme ve Yönetim Bilimleri Fakültesi, İşletme Bölümü \\ enarcikara@medipol.edu.tr
}

\section{ÖZ}

Türkiye Sigorta Sektöründe, 1990 yılında "Yabancı sigorta şirketlerinin piyasaya girişine izin verilmesi" ve "sektörde serbest tarife uygulamasına geçilmesi" ile büyük bir rekabet başlamıştır. Türk sigorta sektörü sigorta bilinci ve prim üretimi düşük olmasına rağmen, yüksek potansiyelli bir sektör olarak dikkat çekmektedir. Uluslararası şirketler, satın alma veya ortaklık yöntemleriyle, sisteme hızla nüfuz etmektedir. Bu çalışmada; şirketlerin pazar payları ve mülkiyet/ortaklık yapılarındaki değişim, tablo ve grafik okuma metoduyla incelenmiş ve "küreselleşmenin”, Türkiye sigorta sektörüne etkisi değerlendirilmiştir. Çalışmada; Türkiye sigorta sektörünün hızla dışa bağımlı hale geldiği ve sektörde "ödenmiş sermaye ve prim üretiminde" uluslararası sermayenin payının oldukça yüksek bir noktaya ulaştı̆̆ tespit edilmiştir.

Anahtar Kelimeler: Sigorta Sektörü, Küreselleşme, Rekabet Stratejileri, Pazar Payı 


\title{
Effects Of Globalization On Turkish Sector: Market Shares And Partnership Structures
}

\begin{abstract}
In Turkish insurance sector, in 1990 with the entry of foreign insurance companies into the market and free tariff implementation, a fierce competition has started, pushing companies into strategic alliances and new investments. Turkish insurance sector has low insurance awareness and premium production, but it is a high potential sector. International companies rapidly penetrate the system through purchasing or partnership methods. In this study; companies' market share and ownership/partnership changes were analyzed with the method of reading tables and graphs. In this study; it has been determined that Turkey rapidly become dependent on foreign paid-up capital and international capital share in premium production is quite high.
\end{abstract}

Keywords: Insurance Sector, Globalization, Competition Strategy, Market Share

\section{GİRİş}

Türkiye'de alınan idari kararlar doğrultusunda belirlenen sigorta tarifeleri 1 Mayıs 1990 tarihinden sonraki tarihlerden kaza sigortası(zorunlu sigortalar hariç) zirai sigortaları ve mühendislik sigortalarında ;1 Ekim 1990 tarihinden itibaren de nakliyat ile yangın sigortalarında "Serbest Tarife Sistemine" geçiş gerçekleşmiştir(tsb.org.tr).Serbest tarife sisteminin yürürlüğe girmesiyle, başlangıçta fiyatlar üzerinde yapılan rekabetler, şirketlerin karlılıkları üzerine baskı oluşturmuş buna paralel olarak bu baskı şirketlerin teknik karlılıklarını hızla aşağıya çekmiştir(Kılıçkaptan ve Karpat, 2004:2). Artan rekabet ve küreselleşmenin etkisiyle sigorta sektöründe yabancı sermaye yatırımları artmış, şirket satın almaları, birleşmeleri ve işbirlikleri sıkça yaşanmaya başlanmıştır.

Sigorta sektörü bağımsız aracılık piyasasında; 1990'ların ortalarından itibaren giderek artan bir “devralma ve birleşme” eğilimi gözlenmektedir(Faure ve Van Den Bergh'den aktaran Tunay, 2015:66).

Sigortalılık oranının düşük, buna karşılık sigorta potansiyelinin yüksek olması nedeniyle uluslararası yatırımcıların Türk sigortacılık piyasasına ilgisi artarak devam etmektedir. Ülkemizde 2001 y1lında faaliyette bulunan toplam 58 şirketin sadece 15'i uluslararası sermayeye sahip iken, 2008 yılından itibaren uluslararası sermayeli şirket sayısı hızlı artış 
trendine girmiş ve 2017 yılsonu itibarıyla bu sayı 44'e yükselmiştir (hazine.gov.tr). Türkiye sigortacılık sektöründe yapılmaya başlayan yabancı sermaye yatırımlarının çoğu ağırlıklı olarak Avrupa Birliği ülkelerinden kaynaklanmakta olup özellikle Almanya ve Fransa'nın Türk sigortacılık sektöründeki sermaye akışı rolü ticari ve ekonomik ilişkilerin yakınlığı sebebiyle büyüktür. (Yücememiş, Akpınar ve Okay, 2011:73).

Çalışmamız üç bölümden oluşmaktadır. Birinci bölümde küreselleşme ve sigorta sektörü hakkında genel bilgiler verilmiş olup, ikinci bölümde Maliye ve Hazine Bakanlığı, Türkiye Sigortalar Birliği ve Hazine Müşteşarlığı'na ait resmi raporlarda elde edilen veriler ile sektörde faaliyet gösteren şirketlerin “ortaklık yapıları" ve "pazar payları”, tablo ve grafik okuma yöntemiyle analiz edilmiştir.

Sektörde faaliyet gösteren şirketlerin ortaklık yapılarının ve pazar paylarının incelendiği çalışmamızın üçüncü ve son bölümünde; elde ettikleri kazançları, Türkiye dışına transfer etmeleri ile önemli bir "dış ticaret açığına" neden olabilme potansiyelindeki yabancı sermayeli şirketlerin "pazar payı ve prim üretiminde” sektördeki durumları incelenmiştir. Türkiye Sigorta sektöründe hizmet sunucular arasında yaratılmak istenen rekabette devlet kontrolü kaybetti mi? sorusuna cevap aranmaya çalışılmış, Türkiye sigorta sektörünün yakın gelecekte karşılaşabileceği olası risklere dikkat çekilmek istenmiştir.

\section{KÜRESELLEŞME}

\subsection{Küreselleşme Kavramı}

Küreselleşmeyle ilgili herkesin üzerinde ittifak ettiği bir tanımı bulunmamaktadır. Türk Dil Kurumu(TDK)'na göre küreselleşme: globalleşme anlamına gelmektedir. Global ise küresel ve toptan anlamlarında kullanılmaktadır. TDK'nun iktisadi terimler sözlügünde 'Uluslararası düzlemde yaygınlaşmış iktisadi etkinliklerin işlevsel anlamda birbirlerine eklemlenmesi” olarak tanımlanmıştır (tdk.gov.tr). Küreselleşmenin kelime olarak kaynağı İngilizcedir. "The Globe” kelimesi dünya, küre, yeryüzü anlamına gelmektedir. "Globe” kelimesinden türeyen "global” ise bütün dünyayı etkileme, yani dünya çapında anlamındadır (Talas \& Bildirici, 2008: 9).

Amerikan Ulusal Savunma Enstitüsü küreselleşmeyi malların, hizmetlerin, paranın, teknolojinin, fikirlerin, bilginin, kültürün ve halkların hızlı ve sürekli bir biçimde sınır ötesine 
akışı biçiminde tanımlamaktadır. Birleşmiş Milletler İnsan Hakları Komisyonu ise küreselleşmeyi "sadece ekonomik olmayan sosyal, siyasal, çevresel, kültürel ve hukuksal boyutları da olan bir süreç” olarak tanımlamaktadır (Öymen, 2000:26-27).

\subsection{Küreselleşmenin Tarihçesi ve Gelişimi}

Küreselleşme; insanların yeryüzüne yayılmalarıyla başlamış ve zamanla artarak ve hızlanarak devam etmiştir (Karabıçak, 2002:118.) Yaratılış inancına göre de insanoğlunun yerküreye yayılmasıyla başlamıştır (Tora ve Aftara 2002: Bereşit, 1,1; İncil, 2012:Matta 19; Kuran-1 Kerim, Elmalı1ı M. H. Yazır, 2014: Bakara 30-38, Zümer 6). Bilim dünyasında küreselleşmenin fark edilmesi ve araştırma konusu yapılması ise yirminci yüzyılda başlamıştır. Avrupa sömürgecilik dönemiyle birlikte son beş yüzyıl içinde küresel ekonominin bütünleşmeye başladığı görülür. Küreselleşmenin son çeyrek yüzyılda bilgisayar teknolojisindeki hızlı gelişmelerle birlikte ülkeler arası ticari sınırlamaların ortadan kaldırılmasıyla ve çokuluslu firmaların politik ve ekonomik kuvvetlerinin artmasıyla hızlandığı kabul edilir (Ellwood, 2002: 13).

Küreselleşme ifadesi, ilk defa Kanadalı sosyoloji profesörü Marshall Mc Luhan tarafından kullanılmıştır. McLuhan 1962 yılında yayınladı̆̆ı "Gutemberg Galaxy” adlı kitabında "global köy” kavramından bahsetmiştir. 1990'lı yılların başlarında bu kavram üzerinde en çok duran Anthony Giddens'e göre küreselleşme, ulusal sınırlar dışında meydana gelen olaylardan etkilenme bağlamında sosyal ilişkilerin dünya ölçeğinde yoğunlaşmasıdır (Elçin, 2012: 2-3).

\section{3. İşletmelerin Küreselleşmesi}

Küreselleşmenin ekonomik boyutu, ekonomik işlemlerin ve ekonomik faaliyetlerin genişleyerek ülke sınırlarını aşması ve artan bir biçimde ekonomilerin dışa açılması, dünyada ekonomik entegrasyonun derinleşmesi olarak karşılıklı ekonomik bağımlılığın artması ile belirginleşmiştir (İncekara, 2011: 5). İşletmelerin küreselleşmesi uluslararası işletmecilik veya çokuluslu şirket kavramlarından daha öte bir kavramdır. Uluslararası işletmecilik iki veya daha fazla ülkenin sınırları içerisinde gerçekleşen her türlü ticari faaliyete verilen addır. Çokuluslu şirketler ise pazarlama ve üretim iştirakleri şeklinde birden fazla ülkede doğrudan yatırımları olan bir işletme şeklidir (Wild, 2017: 4-5).

Pazarlama maliyetlerini düşürmek, yeni pazar fırsatları yaratmak, düzenli gelir akışlarını dengelemek, yerel alıcıların ihtiyaçları, pazarların küreselleşmesi, düşük maliyetli işgücüne 
erişim, teknik uzmanlığa erişim ve üretim girdilerine erişim gibi nedenlerle üretimin küreselleşmesi beraberinde işletmelerin küreselleşmesi sonucunu doğurmuştur (Wild, 2017: 79).

\subsection{Sermayenin Küreselleșmesi}

Paranın konverteble olması, uluslararası para transferini mümkün kılan bankacılık altyapısının kurulması, uluslararası kredi ve tahvil piyasaları, hisse senedi piyasaları, türev piyasaları ve kredi kartları finansal küreselleşmenin gerçekleşmesini sağladı. Finansal küreselleşme ile birlikte sermayenin küreselleşmesi süreci kolaylaşmış, sermayenin ülke sınırlarına bağlı kalmaksızın doğrudan ya da dolaylı olarak dünyanın her yerinde yatırımlarını gerçekleştirmesinin önü açılmıştır. Sermayenin küreselleşmesi sonucunda küresel işletmeler oluşmuştur.

Küresel ticaretin önündeki engellerin kaldırılması için ekonomik işbirlikleri ve uluslararası örgütler kurulmuş ayrıca çok taraflı uluslararası anlaşmalar imzalanmıştır. Dünya liderlerinin ve ekonomi bakanlarının katıldığı D8, D20 ve Davos toplantıları düzenli olarak yapılmaktadır. Günümüzdeki karşılığ1 Dünya Ticaret Örgütü(WTO) olan Tarife ve Ticaret Anlaşması'nın faaliyetleri son zamanlarda ticari serbestleşme akımlarıyla ekonomik entegrasyon faaliyetleriyle devamlılı̆̆ını sürdürmektedir(İncekara, 2011:12).

Dünyada ekonomik olarak ilk entegrasyon hareketleri Zollverein gümrük birliğiyle 1834 yılında Alman devletleri arasında düzenlenmiş olup takip eden y1llarda ise bu entegrasyon durumunun hız kazanması II.Dünya Savaşıyla birlikte Tarife ve Ticaret Genel Anlaşması'nın (GATT) kabulü ve Dünya Ticaret Örgütü’ne (WTO) dönüştürülerek kurumsal bir yapı içerisine girmiştir.Bu ilerleme sonucunda Avrupa,Kuzey Amerika ve Asya-Pasifik’te büyük ekonomik bütünleşme hareketleri gerçekleştirmiştir (Mill, 2017:21).

Günümüzde globalleşmenin yaygınlaşmasına katkıda bulunan ekonomik birliktelikler Avrupa merkezli AB, Asya-Pasifik merkezli ABD, ÇİN ve Rusya'yı da içine alan APEC, ve Kuzey Amerika merkezli NAFTA'dır. Bu birlikteliklerin ortak özelliği gelişmiş ülkelerin kurduğu birliktelikler olmalarıdır. 


\subsection{Türkiye’nin Ekonomik Küreselleşmesi}

Genel olarak Türkiye, dünya ekonomik küreselleşme ortalamasının altında bir seyir göstermektedir. Türkiye'nin ekonomik endeksinin bu derece düşük olması üzerinde durulması gereken önemli bir husustur. Ekonomik endeksin düşük olmasına ticarete ilişkin verilerin düşük olması mı yoksa kısıtlamaların yüksek olması mı yoksa her ikisi birden mi neden olmuştur konusu ayrı bir inceleme konusudur. İlk 100 ülkenin son 20. Sirasında ise Türkiye yer almaktadır. Türkiye 2016 yılı verilerine göre $\% 53$ ekonomik globalleşme oranına sahiptir. $\mathrm{Bu}$ oranla birinci olan Singapur ile arasında 40 puan yüzde farkı oluşmuştur.

Şekil 1: Türkiye Küreselleşme Trendi

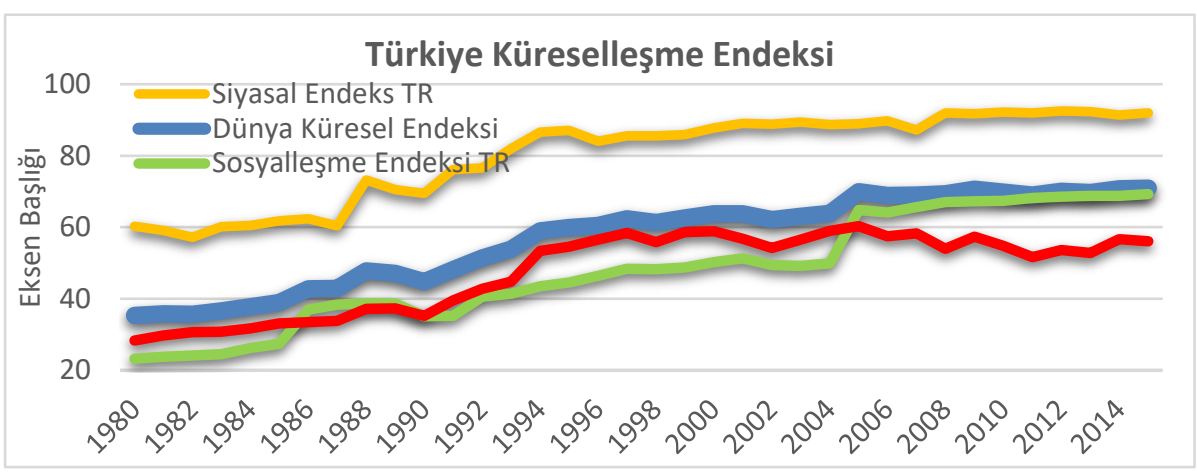

Kaynak:https://www.kof.ethz.ch/en/forecasts-and-indicators/indicators/kof-globalisationindex.html

Türkiye'nin küreselleşmesi siyasal olarak dünya ortalamasının üstünde yer almakla birlikte ekonomik ve sosyalleşme olarak dünya ortalamasının altında bir seyir izlemiștir. Sosyalleşme endeksinde son dönemlerde ortalama yakalanmış olmakla birlikte ekonomik globalleşme de son y1llarda ortalamadan uzaklaşma durumu görülmektedir.

Şirketlerin küreselleşmesinin ölçülmesi ülke küreselleşmelerinin ölçülmesinden farklı hesaplanmaktadır. Birçok çalışmada endüstri küreselleşmesini ölçmek amacıyla farklı ölçüm teknikleri ve kriter kullanılmıştır. Endüstri küreselleşmesinin tarafsız ve anlaşılabilir ölçümü için endüstride yer alan firmaların katma değer faaliyetlerinin ulusal sınırlar arasındaki bütünleşme derecesi ile endüstrinin uluslararası bağlantılarının derecesinin belirlenmesine ihtiyaç vardır (Chen, 2004: 3).

Gelişmekte olan ülkeler için yapılan analizler değerlendirildiğinde; gelişmekte olan ülkelerde doğrudan yabancı yatırımların (DYY) girişi ile sosyal küreselleşme gelir eşitsizliğini artırırken, 
dışa açıklık, politik küreselleşme ile ekonomik küreselleşmenin gelir eşitsizliğini azalttığı sonucuna ulaşılmıştır. Uzun dönem nedensellik test sonuçlarına göre gelişmekte olan ülkeler için uzun dönemde dışa açıklık, DYY, politik, sosyal ve ekonomik küreselleşmenin gelir eşitsizliğinin nedeni olduğu görülmektedir (Demir, 2018: 99). Aynı zamanda küreselleşme; dijital bağımlılık, siber zorbalık, bireyin sosyalleşmesi ile ilgili problemler ve kültürel problemler gibi insanlığın uğraşmak zorunda kaldığı bir takım yeni sorunları da beraberinde getirmiştir (Kesici, 2018:238).

Küreselleşme karşıtlarının beklentilerinin aksine dünya hızla küreselleşme yolunda ilerlemektedir. Küreselleşmenin her ülke için ve her sektör için farklı sonuçları olacaktır. Küreselleşmenin faydalarından daha fazla yararlanmak isteyen ülkeler faydalarını en yükseğe çıkaracak, zararlarını da en aza indirecek politikalar peşinde koşmaya devam edecektir. $\mathrm{Bu}$ anlamda, neredeyse bütün sektörler küreselleşmenin getirdiği avantajları elde etmek için faaliyetlerini global ölçeğe çekmeye çalışmaktadır. Bu çalışmanın ortak noktası olan sigortacılık sektörü de bu anlamda dikkat çeken sektörlerden biridir.

\section{SIGGORTA SEKTÖRÜ}

\subsection{Sigorta Kavramı}

Sigorta ve sigortacılık kavramı ile ilgili birçok farklı tanım bulunmaktadır. Türk Dil Kurumuna göre "sigorta"; bir kimsenin herhangi bir istikametten ileride karşılaşabileceği zararı gidermek için evvelce ödenen prim karşılığında bu işle uğraşan kuruluşla yaptığı iki taraflı kontrat olarak tanımlanmaktadır. Bu sözleşme ile sigorta şirketleri, sigortaladıkları kişinin karşılaşması olası risklerden doğacak kayıp ve zararı karşılamayı taahhüt ederler. Risk ise gerçekleşme ihtimali olan ancak ne zaman gerçekleşeceği belli olmayan, muhtemel kayıp ve zararlardır(tdk.gov.tr).

9 Temmuz 1956 tarih ve 9353 sayılı Resmi Gazete'de yayımlanarak yürürlüğe giren 6762 sayılı Türk Ticaret Kanunu'nun 1263. Maddesinde sigorta; "Sigorta bir akittir ki, bununla sigortac1 bir prim karşılığında diğer bir kimsenin para ile ölçülebilir bir menfaatini halele uğratan bir tehlikenin meydana gelmesi halinde tazminat vermeyi yahut bir veya birkaç kimsenin hayat müddetleri sebebiyle veya hayatlarında meydana gelen belli bir takım hadiseler dolayısıyla bir para ödemeyi veya sair edalarda bulunmayı üzerine alır" şeklinde tanımlanmaktadır (resmigazete.gov.tr). 
Sigorta, aynı rizikonun tehdidi altında bulunan bir topluluğun bir araya gelerek doğabilecek hasarlara beraber karşı koyması olarak tanımlanır. Sigorta kavramının temelinde risklerle dolu bir dünyada yaşayan insanların gerçekleşmesi olası risklerin yol açacağı hasarların giderilmesi emeliyle riskin oluşmasından önce bazı önlemler alma gereği yatmaktadır (Şenel, 2007:7).

Reasürans ise sigorta edilmiş rizikonun, belli bir bölümünün veya tamamının yine sigorta edilmesidir. Sigorta şirketleri, güvence verdikleri rizikolarda büyük hasarların aynı vakte gelme olasılığına karşı, hasar ödemelerinde zorlanmamak için reasürans (mükerrer sigorta) yaptırır. Reasürans, sigorta şirketlerine, tek başlarına yüklenmeleri kendi anaparaları, temkinleri, özvarlıkları itibariyle k1saca mali istikametten olası olmayan rizikoları, sigortalayabilme olanağ1 verir (tsb.org.tr).

\subsection{Türkiye Sigorta Sektörü}

2017 y1lı sonu itibarıyla 60'1 ilk sigorta ve 2'si reasürans şirketi olmak üzere 62 şirket faaliyet göstermektedir (hazine.gov.tr). Sermaye yapılarına göre bu şirketlerin 7'si kamuya (özelleştirme programına alınmıştır) aittir. Aksigorta A.Ş., Anadolu Türk Sigorta A.Ş., Anadolu Hayat Emeklilik A.Ş., Avisa Emeklilik ve Hayat A.Ş., Güneş Sigorta A.Ş., Halk sigorta A.Ş. ve Ray Sigorta A.Ş. Borsa İstanbul'da işlem görmektedir (kap.org.tr). Ülkemizde sigortacılık ve bireysel emeklilik sistemi sektörlerinde faaliyet gösteren 62 sigorta, reasürans ve emeklilik şirketinde, 2017 yılı sonu itibarıyla toplam 19.883 kişi istihdam edilmektedir (hazine.gov.tr).

Sigortanın tasarrufu teşvik işlevi ve fonlardaki birikimlerin etkin yatırımlara yönlendirilmesi ülke kalkınmaları için ehemmiyetli bir rol taşımaktadır. Gelişmiş ülkelerde sigorta ve reasürans şirketlerinde biriken fonların etkin yatırım alanlarına kanalize edilmesi sonucu, sigorta işlemlerinde teknik zarar olsa bile yatırım gelirleriyle büyük karlar elde edilebilmektedir (Çiftçi, 2004: 134-135).

2017 y1lında aktif hesap kalemlerinin \%14,2'sini oluşturan finansal varlıklar içerisinde kamu borçlanma senetleri ilk sırayı almaktadır. Bu durum, kamu borçlanma senetlerinde getirinin enflasyon oranının üzerinde, ayrıca karşılığının kesin ve devlet garantisi altında olmasından kaynaklanmaktadır. Sektörde 2017 yılında 18,8 milyar TL'ye ulaşan toplam finansal varlıkların yaklaşık \%72'si serbest, \%28'i ise sigorta sözleşmelerinden doğan taahhütlere karş1lık olmak üzere Hazine Müsteşarlığı lehine bloke edilmiş kıymetlerden oluşmaktadır(hazine.gov.tr). 
Türkiye Sigorta Birliği verilerine göre, 2016 yılında sigorta sektörü, toplam 40.489 milyon TL pirim üretimi gerçekleştirerek önceki yıla (2015) göre \%32'ye yakın bir artış, 2017 yılında ise 46.556 milyon TL prim üretimi ile bir önceki yıla göre (2016) \%15'e yakın bir artış sergilemiştir (hazine.gov.tr).

Zorunlu trafik, ihtiyari mali sorumluluk, genel sorumluluk, finansal kayıplar, hukuksal koruma, yangın ve doğal afetler, hava araçları sorumluluk, kredi, su araçları, hava araçları, kaza, hastalık/sağlık, doğrudan kefalet, nakliyat, genel zararlar ve kara araçları sigortacılı̆̆ı gibi birçok branşta sigortacılık faaliyeti yürütülmektedir. Ülkemizde sigorta güvencesi ihtiyari ve zorunlu olmak üzere iki türlü uygulanmaktadır. Zorunlu trafik sigortasından ayrı olarak, patlayıcı maddeler ihtiva eden işyerleri ve çalışanları, otobüs yolcuları, kaynak atölyeleri, bazı meslek grupları, oto tamirhaneleri vb. işyerleri zorunlu sigorta uygulamasına tabidirler.

Tablo 1: Prim Üretimi ve Teminat Tutarlarının Seyri

\begin{tabular}{|c|c|c|c|c|c|}
\hline (Milyon) & 2013 & 2014 & 2015 & 2016 & 2017 \\
\hline \multicolumn{6}{|l|}{ Prim Üretimi } \\
\hline $\begin{array}{l}\text { Hayat D1şı Prim } \\
\text { Üretimi }\end{array}$ & 20.832 & 22.711 & 27.296 & 35.450 & 39.712 \\
\hline Hayat Prim Üretimi & 3.395 & 3.280 & 3.761 & 5.039 & 6.844 \\
\hline Toplam Prim & 24.227 & 25.991 & 31.761 & 40.489 & 46.556 \\
\hline Hayat Dışı Payı (\%) & 85,99 & 87,38 & 87,89 & 87,55 & 85,3 \\
\hline Hayat Payı (\%) & 14,01 & 12,62 & 12,11 & 12,45 & 14,7 \\
\hline \multicolumn{6}{|l|}{ Teminat Tutarı } \\
\hline $\begin{array}{l}\text { Hayat Dışı Teminat } \\
(*)\end{array}$ & 62.334 .348 & 75.961 .929 & 85.389 .071 & 89.115 .156 & 106.268 .467 \\
\hline Hayat Teminat1 & 485.712 & 564.914 & 670.804 & 746.487 & 918.264 \\
\hline Toplam Teminat & 62.820 .060 & 76.526 .843 & 86.059 .875 & 89.861 .644 & 107.186 .731 \\
\hline
\end{tabular}

Kaynak: Maliye ve Hazine Bakanlığı Sigorta Denetleme Kurulu, Türkiye'de 2017 Yılı Sigortacılık ve Bireysel Emeklilik Faaliyetleri Hakkında Rapor, 2017(*) Hastalık/Sağlık Branş1 Hariç - Excluded Health and Sickness.(**) Magdeburger Sigorta AŞ'nin Riskli Sigortalılar Havuzu'ndan gelen 21,4 milyon TL endirekt prim üretimi dahil edilmemiştir.

2016 yılında Türkiye Hayat prim üretiminde dünyadaki toplam prim tutarının \%6'sını meydana getirmekte ,dünyada 47'inci Avrupa'da 22'inci sıradadır.2016 yılında Türkiye Hayat Dışı prim üretiminde dünyadaki toplam prim tutarının \%54'ünü meydana getirmekte ve dünyada 22'inci,Avrupa'da ise 11'inci sırada yerini almıştır.2016 yılında sigorta primlerinin hayat branşındaki oranı \%0,19 ,hayat dışı branşında \%1,36 olup GSYİH’ya oranı ise toplamda 
\%1,55'tir.Avrupa'da 28'inci sırada yer alırken dünyada 73'üncü sırada yer almaktadır. .(tsb.org.tr/ Swiss Re, Institute sigma, No: 3/2017: 37).

Geride bıraktığımız yıllar içerisinde çok sayıda yenilikçi ürün ve hizmeti hayata geçiren şirketler, ürün portföyünü çeşitlendirerek rekabette ön plana çıkmaya devam etmiştir. $\mathrm{Bu}$ bağlamda yıllardır sektörün en önemli branşı olan kasko ve trafik sigortalarının yanı sıra iş yeri sigortaları, sektörlere özel paketler, nakliyat sigortaları, sağlık, mühendislik ve sorumluluk sigortaları gibi ürünlerin de ciddi gelişme göstermesi beklenmektedir. Ancak, 2018 yılı içerisinde kurda yaşanan sert dalgalanmalar ile faiz ve enflasyon oranlarındaki artış göz önüne alındığında, sigortacılık sektörünün prim üretimi üzerinde baskı yaratacağını öngörmek de yanlış olmayacaktır. Döviz kurlarındaki sert yükseliş özellikle kasko, trafik ve sağlık sigortaları gibi yurt dışı bağımlı branşları olumsuz etkileyebilecektir.

\subsection{Türkiye Sigorta Sektörünün Çekiciliği ve Potansiyeli}

Genel anlamda, kişilerin iş ve sosyal yaşamlarında kendilerini güvende hissetmek istemesi ile beklenmedik risk ve kazalara karşı korunmak ihtiyacı sigorta ürünleri çekici kılmaktadır. Türkiye sigorta sektörü, sigorta bilincinin ve prim üretiminin düşük olduğu, henüz beklenen noktaya ulaşmamış; ancak gelişimini ve büyümesini sürdüren yüksek potansiyelli bir sektör olarak dikkat çekmektedir.

Dünya ortalaması 650 USD iken Türkiye'de 2017 yılında kişi başı prim üretimi 149 USD olmuştur. Bu da aslında pazarın büyüme potansiyelini göstermektedir. Uluslararası sermayenin Türkiye'deki sigortacılık faaliyetlerinin artarak gelişmesini açıklayan bir başka etmen bu potansiyeldir. Dünya genelinde faaliyet gösteren en büyük oyuncular Türkiye'de varlıklarını sağlamlaştırmak istemektedir.

Tablo 2: 2017 Yı1ı Kişi Başı Prim Üretimi ve Direkt Prim Üretimi/GSYH Oranı

\begin{tabular}{|l|c|c|}
\hline \multicolumn{2}{|c|}{2017 Yılı Kişibaşı Prim Üretimi ve Direkt Prim Üretimi/GSMH Oranı } \\
\hline (ABD Doları) & Kişi Başına Prim Üretimi & Prim/GSMH \\
\hline Gelişmiş Piyasalar & 3517 & 7,76 \\
\hline Gelişmekte Olan Piyasalar & 166 & 3,34 \\
\hline
\end{tabular}




\begin{tabular}{|l|l|l|}
\hline Türkiye & 149 & 1,42 \\
\hline Dünya & $\mathbf{6 5 0}$ & $\mathbf{6 , 1 3}$ \\
\hline
\end{tabular}

Kaynak: Sigma Dergisi, 2017 Dünya Sigortacılığı, Source: Sigma Magazine, World Insurance in 2017, No: 3/2018

Türkiye'nin kentleşme oranının ve nüfusunun hızlı artışı ile ekonomideki büyüme ve gelişmeler sigorta sektörüne bakış açısını da önemli ölçüde değiştirmektedir. Aynı zamanda sigorta şirketlerinin mali kaynaklarının güçlü olmasından ötürü, sigortalılar için genel anlamda mağduriyet teşkil etmemesi bu sektöre duyulan güveni artırmaktadır. Toplumda hak arama bilinci ve kültürünün artması ile birlikte hukuk bürolarına da ilgi artmıştır. Önümüzdeki dönemlerde bazı meslek gruplarına yönelik tazminat davalarında önemli bir artış olması beklenmektedir. Bunun karşılığında da mesleki sorumluk sigortaları ile özel sağlık sigortalarında ve tamamlayıcı sağlık sigortalarında artış yaşanması beklenmektedir.

\subsection{Türkiye Sigorta Sektöründe Pazar Payı}

Pazar payı, işletmelerin pazardaki yerini ve sıralamasını gösterdiğinden dolayı pazar payındaki meydana gelen değişme ve gelişmeler işletmeler için bir ölçü olarak değerlendirilmektedir. Özellikle karlılığı doğrudan etkilemesinden ötürü, pazar payı işletmeler için önemli bir karar kriteri olup yıldan yıla paydaki meydana gelen değiş̧iklikler yakından takip edilmelidir (Dinçer, 2003: 95).

2017 yılında Türkiye'de toplam 39.712 milyon TL'lik hayat dışı ve 6.844 milyon TL'lik hayat poliçesi olmak üzere 46.556 milyon TL' lik satış gerçekleştirilmiştir. Türkiye Sigortalar Birliği’nin 17.03.2017 tarihinde yayınladığı Pazar payı istatistiklerine göre Allianz A.Ş. 5.134 milyon TL satış ile sektördeki en büyük paya sahiptir. Allianz A.Ş.'ni sırasıyla Anadolu Anonim Türk Sigorta Şirketi, Axa Sigorta A.Ş., Mapfre Sigorta A.Ş., Sompo Japan Sigorta A.Ş. ve Aksigorta A.Ş. izlemektedir.

Türkiye Sigorta sektöründe yaşanan yoğun rekabet şirketlerin karlarını istendiği ölçüde artırmalarına engeldir. Bu durum şirketler, sektörde varlıklarını sağlamlaştırmak için en önemli etken olan pazar paylarını artırmaya odaklanmışlardır. 
Tablo 3: Türkiye Sigorta Sektörü Prim Üretimi ilk 10 şirket

\begin{tabular}{|c|l|r|r|}
\hline & Şirket Adı & Toplam Üretim & Pazar Payı (\%) \\
\hline $\mathbf{1}$ & Allianz Sigorta AŞ & 5.134 .074 .128 & 12,93 \\
\hline $\mathbf{2}$ & Anadolu Ananim Türk Sigorta Şirketi & 4.671 .409 .652 & 11,76 \\
\hline $\mathbf{3}$ & Axa Sigorta AŞ & 2.908 .210 .170 & 7,32 \\
\hline $\mathbf{4}$ & Mapfre Sigorta AŞ & 2.680 .402 .015 & 6,75 \\
\hline $\mathbf{5}$ & Aksigorta AŞ & 2.635 .576 .300 & 6,64 \\
\hline $\mathbf{6}$ & Sompo Japan Sigorta AŞ & 2.263 .371 .718 & 5,7 \\
\hline $\mathbf{7}$ & Ziraat Sigorta AŞ & 1.736 .337 .797 & 4,37 \\
\hline $\mathbf{8}$ & Güneş Sigorta AŞ & 1.660 .979 .253 & 4,18 \\
\hline $\mathbf{9}$ & Doga Sigorta AŞ & 1.491 .503 .094 & 3,76 \\
\hline $\mathbf{1 0}$ & Halk Sigorta AŞ & 1.480 .370 .603 & 3,73 \\
\hline & İLK 10 ŞíRKET TOPLAM & $\mathbf{2 6 . 6 6 2 . 2 3 4 . 7 3 0}$ & $\mathbf{6 7 , 1 4}$ \\
\hline
\end{tabular}

Kaynak: Türkiye Sigorta Birliği, Prim Üretimi Resmi İstatistikleri, 2017.

\subsection{Türkiye Sigorta Sektöründe Şirketlerin Satış ve Dağıtım Kanalları}

Sigorta sektöründe, şirketler arasında yoğun bir rekabet söz konusudur. Geçmiş dönemde sadece şirketler arasında olan rekabet, günümüzde acenteler ve banka şubeleri arasında yoğun bir şekilde yaşanmaktadır. Bir hizmet türü olan sigorta hizmetinin de müşteriye ulaştırılması için seçebileceği iki yol vardır. İlki, pazarlama sürecinde doğrudan dağıtım kanalı olarak ifade edilen işletmenin hizmeti müşteriye doğrudan kendi ulaştırması, diğeri ise dolaylı dağıtım kanalı olarak adlandırılan işletmenin bir veya daha fazla aracı yardımıyla hizmeti müşteriye ulaştırmasıdır. Pazarlama sürecinde dağıtım kanalının hızı, güvenilir oluşu ve satış gücü gibi etkenler, pazarlama açısından oldukça önemlidir (Dursun ve Gürsev, 2016: 557).

Dağıtım kanalları içerisinde acentelerin payı son beş yılda yatay bir seyir izlemiştir. Buna ek olarak Sigorta sektöründe dolaylı dağıtım kanalları genel olarak; brokerler, bankalar ve acenteler olmak üzere üç gruba ayrılmaktadır. Bu ayırım içinde özellikle acentelerin, bir sigorta şirketi için ehemmiyeti oldukça fazladır. Diğer, dağıtım kanallarının (bankasürans ve brokerler gibi) sektör içindeki payları dönemsel ekonomik koşullara bağlı olarak değişkenlik gösterse de, acentelerin sigorta sektörü açısından ne kadar önemli olduğu ve gelecek yıllarda da bu durumun benzer şekilde olacağı tartışılmaz bir gerçektir (Akpınar, 2017:55).

Acentelerde serbest olan aracılar içerisindeki üstün olma durumuna zit olarak, brokerların perakende ve toptancı sigorta piyasalarında önemli derecede üstünlük sahibi oldukları 
söylenebilir. Bu eğilim hem ulusal hem de uluslararası piyasalarda da görünmektedir (Tunay, 2015: 69). 2017 yılında direkt prim üretimi hayat ve hayat dişı için \%52,1'i özel acenteler, \%31,2'si banka acenteleri ve \%11,1'i brokerler aracılığıyla, \%4,6's1 ise doğrudan şirketler tarafından gerçekleştirilmiştir (hazine.gov.tr).

Banka şubelerinin satışta artan önemine rağmen son beş y1llık periyotta acentelerin hayat dış1 branşlarda \%59,92, hayat dışı branşlarda ise \%82,41 gibi önemli bir oranda dağıtım kanallarında başı çektiği görülmektedir.Acenteler üzerinden yapılan satışlar \%52,1 ile başı çekmektedir. Birçok ülkede olduğu gibi, serbest faaliyet gösteren acentelerin en önemli rakibinden biri banka şubesi satışları $(\% 31,2)$ olduğu ve Türkiye'de de aynı durumun görüldüğü unutulmamalıdır. Bünyesinde Banka bulunduran holdinglerin ortağı olduğu sigorta şirketlerinde banka üzerinden yapılan satışlar dikkat çekmektedir. Özellikle kredi kullanımı esnasında bu poliçeler tanzim edilmektedir (konut kredisi esnasında yapılan DASK ve hayat sigortası, taşı1 kredisi esnasında yapılan trafik ve kasko sigortası ve ihtiyaç kredisi ile birlikte yapılan sağlık sigortaları vb.). İnternet üzerinden yapılan e-ticaret sigorta sektöründeki satış işlemlerinde henüz beklenilen düzeye ulaşmamıştır.

\subsection{Sigorta Sektöründe Rekabet}

İşletmelerin çevreleriyle uyumlu ve kendileri için rekabet üstünlüğü sağlayacak stratejileri seçebilmesi oldukça karmaşık bir süreçtir. $\mathrm{Bu}$ süreç pazarın özelliklerine, işletmenin özelliklerine, kullanılan teknolojinin özelliklerine, çevresel değişkenliklerin hızına ve kapsamına göre farklı stratejik kararlar vermeyi gerektirmektedir (Dinçer, 2003: 235). Bilhassa globalleşme ve uluslararası rekabet süreci, bir sistem olarak işletmelerin stratejiye ve stratejik yönetimi algılama açısından daha da fazla önem vermeyi gerektirmektedir. (Alayoğlu, 2010:28).

Her ne kadar işletmelerin rekabet koşulları oldukça farklılık gösterse de, birçok işletme üç stratejiden birini izler. İşletmelerin kendi, tedarikçiler ya da müşterilerin maliyetini düşürmeye çalıştığ ya da rakiplerinin maliyetlerini artırmaya çalıştığı maliyet liderliği stratejisi; ürün ve hizmetleri ile müşterilerine rakiplerine göre daha fazla değer vermeyi hedeflediği ürün farklılaştırma stratejisi; ürün ve hizmetlerini sadece belirli pazarlara sunmayı hedeflediği odaklanma stratejisi (Porter, 1985: 54). 
Sürmeli ve Yükselen (2000), yaptıkları araştırmalar sonucunda rekabet üstünlüğüne yol açan 11 faktör ortaya koymuşlardır. Bunlar; pazarlama üstünlüğü, üretim etkinliği, kalite üstünlüğü, faaliyet süresi, dağıtım ve üretim ve pazarlama maliyetleri, tutundurma politikası, yönetici özellikleri, müşteri isteklerini karşılama düzeyi, ihracatta risk yüklenme düzeyi, kapasite kullanım oranı, satış etkinliği ve yeni mamul geliştirme performansıdır.

Yabancı sigorta şirketleri, Türk sigorta şirketlerini satın alarak veya ortak olarak sisteme nüfuz etmektedir. Mali güçleri açısından büyük bir farkla pazarımıza gelen yabancı sigorta şirketleri; benchmarking, inovasyon, diş kaynaklardan yararlanma ve değişim mühendisliği gibi uyguladıkları modern yönetim teknikleriyle rekabet üstünlüğü sağlamaktadırlar (Kamilçelebi ve Okur, 2010: 33 ).

Sigorta sektöründe birleşme ve devralmaların yanı sıra, şirketlerinin kendi aralarında ve sektör ile yakından ilişkili diğer sektörlerle yaptıkları işbirliklerine sıkça rastlanmaktadır. Avrupa'nın en büyük sigorta şirketlerinden biri olan Ageas, faaliyetlerini dünyanın en büyük küresel sigorta pazarını oluşturan Asya ve Avrupa üzerinde yoğunlaştırmıştır. Ageas; Çin, Malezya, Hindistan, Tayland, Vietnam, Filipinler ,Türkiye ,Belçika, İngiltere, Lüksemburg, Fransa, İtalya ve Portekiz'de başarılı ortaklıklar yürütmektedir. 2011 yılında Sabancı Holding'in Belçikalı dünya devi Ageas ile yaptığı ortaklığın sonrasında, Sabancı Holding \%36, Ageas \%36 hisseye sahip olmuştur. Kalan \%28'lik hisse ise İMKB ulusal pazarında işlem görmektedir (Aksigorta.com.tr).

2016 yılında Aksigorta, sektörde yeni bir iş birliği modelini Acıbadem Sigorta ile imza atmıştır. Gelişmiş sigorta pazarlarında uygulanan, ancak Türkiye'de bir "ilk” olma özelliği taşıyan yeni iş modeli ile Aksigorta'nın satış gücü ve geniş dağıtım kanallarındaki deneyimi ile Acıbadem Sigorta'nın sağlık sigortalarındaki uzmanlığı ve gelişmiş altyapısının yarattığ özel sağlık alanında müşterilerin lehine önemli bir rekabet ortamı yaratılmak istenmiştir (Aksigorta.com.tr).

Aktif Bank iştirak Yeni Sigorta ve Reasürans Brokerliği ve Fiba Holding iştiraki Fiba Emeklilik Grup Kredi Hayat Sigortası ve Bireysel Emeklilik sektöründe büyümek için güçlerini birleştirdiler. Sektörün iki önemli oyuncusu aralarında imzaladıkları bu iş birliği anlaşmasıyla gelecek 5 yıl içerisinde 700 Milyon TL hayat sigortası prim üretimi ve 300 Milyon TL BES fon büyüklüğü amaçlamaktadırlar. (aktifbank.com.tr). 
Türkiye'de yeni yatırım ve işbirlikleri gerçekleştirmeyi hedefleyen Avrupa'nın önde gelen sigorta şirketlerinden biri olan Hollandalı Eureko, Garanti Sigorta'nın \% 80'ini 365 milyon Euroya, Garanti Emeklilik'in ise \% 15'ini 100 milyon Euroya satın almıştır (garantiemeklilik.com.tr).

2017 Aralık ayında düzenlenen Webrazzi Fintech2017 konferansında sahneye çıkan girişimlerden biri olan e-kira, 2018 yılına hızlı bir başlangıç yaparak Anadolu Sigorta ile iş birliğine gitmiştir. E-kira üzerinden fatura, kira ve aidat ödemelerinin en az 2 tanesinin ödemesini gerçekleştiren kullanıcılar Anadolu Sigorta'nın konut sigortası hizmetinden 1 yıl süresince ücretsiz yararlanabilmektedir (webrazzi.com.tr).

180 yıllık sektör deneyimine sahip olan Generali Sigorta ile dünyadaki lider firmalar arasında yerini alan RE/MAX ülkemizde 18 yıldır faaliyet göstermiş bu süre zarfında ev satın alanlara, kiralayanlara ve evinin satış-kiralama işlemlerini RE/MAX ile yürütenlere kolaylık, güvence ve avantaj sağlamasını hedeflemişlerdir(sigortagundem.com) .

Sigorta sektörünün öncü şirketlerinden biri olan AXA SİGORTA sigortalılarına yeni bir hizmet sunmak için, kredi kartı bilgilerinin korunmasını hedefleyen "Uluslararası Kredi Kartı Veri Güvenliği Standartları” çerçevesinde, ülkemizde bankalar arası kredi kartı işlemlerinin hizmet sağlayıcısı olan BKM (Bankalar arası Kart Merkezi) ile müşteri güvenliği konusunda sektörde ilk olan ortak bir projeye imza atmıştır (axasigorta.com.tr).

Allianz Hayat ve Emeklilik ürünlerinin satışı için HSBC Türkiye ile 10 yıllık münhasır bankasürans anlaşması imzalamıştır. Kurumsal ve bireysel müşterilere hizmet sunmayı amaçlayan işbirliği, HSBC'nin Türkiye'deki şube ağı aracılığıyla gerçekleştirilecektir (allianz.com.tr).

Rekabetin çok daha acımasız yaşandığg, küresel rekabet ortamında; rekabet üstünlüğü sağlamak ve sürdürmek isteyen işletmelerin, stratejik işbirliklerinin yanı sıra bilişim sistemlerinden yoğun bir şekilde faydalanmaları gerekmektedir.

\subsection{Türkiye Sigorta Sektöründe Küreselleşme}

Tüm dünyada küreselleşmenin yoğun yaşandığı sektörlerden biriside "sigortacılık” sektörüdür. Altıer'e (2007) göre, Türkiye'de hizmet sektöründe en fazla finansman alabilen üç ana sektör ise; sigortacılık,bankacılık ve telekomünikasyondur.Sektördeki liberalleşme süreci sonucunda 
pek çok ülkede azaltılan kısıtlar doğrudan yabancı yatırımları çeken özelliklerden birisi olmuştur. Bilhassa şirket birleşmesi ve satın almalarındaki kısıtların aza indirgenmesi bu sektördeki yabancı yatırımlara ivme kazandırmıştır (Gövdere, 2009 :66). Türkiye sigorta sektörü 1990 sonrası küreselleşmenin etkisi altına girmiştir.

Şekil 2:Türkiye Sigorta Sektörü Uluslararası Ortaklı Şirket Sayısı (2001-2017).

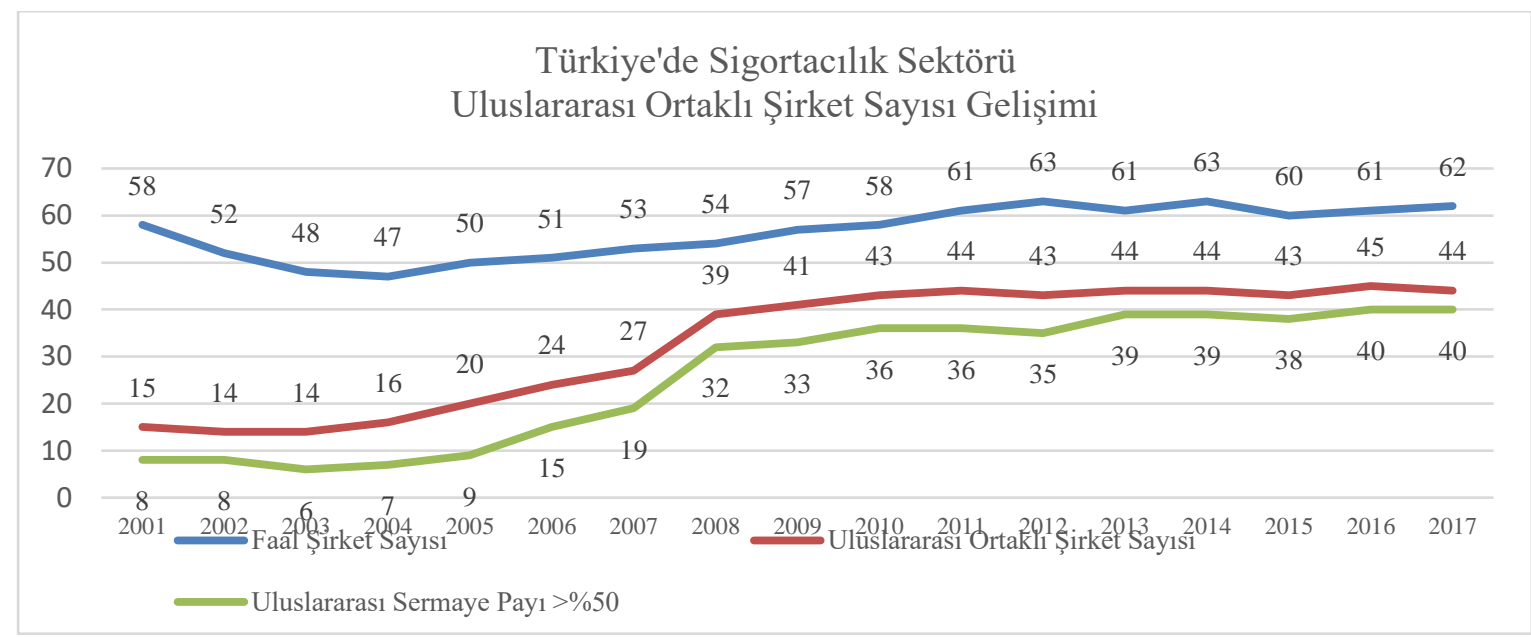

Kaynak:Maliye ve Hazine Bakanlığı Sigorta Denetleme Kurulu, Türkiye'de 2017 Y1lı Sigortacılık ve Bireysel Emeklilik Faaliyetleri Hakkında Rapor.

2007 Haziran ayında yürürlüğe girmiş olan yeni sigortacılık kanunu ,bu alandaki şirketleri mali olarak kalkınmış ,süreçlerdeki anlaşmazlıkları çözüme kavuşturmuş, bu da sektörün daha geniş tabana yayılmasında güvenlik ve esneklik sağlanmıştır. (Yücememiş, Akpınar ve Okay, 2011:71). 2008 yılı itibarıyla sektördeki uluslararası ortaklı şirket sayısında belirgin bir ivmelenme yaşanmış ve 2007 yılında yabancı sermaye payının \%50'nin üzerinde olduğu şirket sayıs1 19 iken bu sayı 2008 yılında 32'ye yükselmiştir.

Şekil 3'de Türkiye'deki sigorta şirketlerinin sermaye paylarının yıllar itibariyle gelişimi gösterilmiştir. 2013 yılından itibaren yabancı sermayeli şirketlerin sermaye paylarındaki artış hızı durağan hale gelmiş ve \%70’ler seviyesinde seyretmiştir. Türkiye'nin ekonomik küreselleşmesinin aksine sigorta şirketlerinde küreselleşmesi oranı daha yüksek gelişmiştir. Türkiye'nin ekonomik küreselleşmesi son y1llarda \%52-55 bandında seyrederken sigorta sektöründe küresel şirketlerin sermaye payı \% 70’lerin üstüne çıkmıştır. 
Şekil 3: Hayat dışı ve hayat sigorta şirketlerinin ödenmiş sermaye paylarına göre ve prim üretimlerine göre oransal olarak uluslararası sermaye payları (2001-2017).

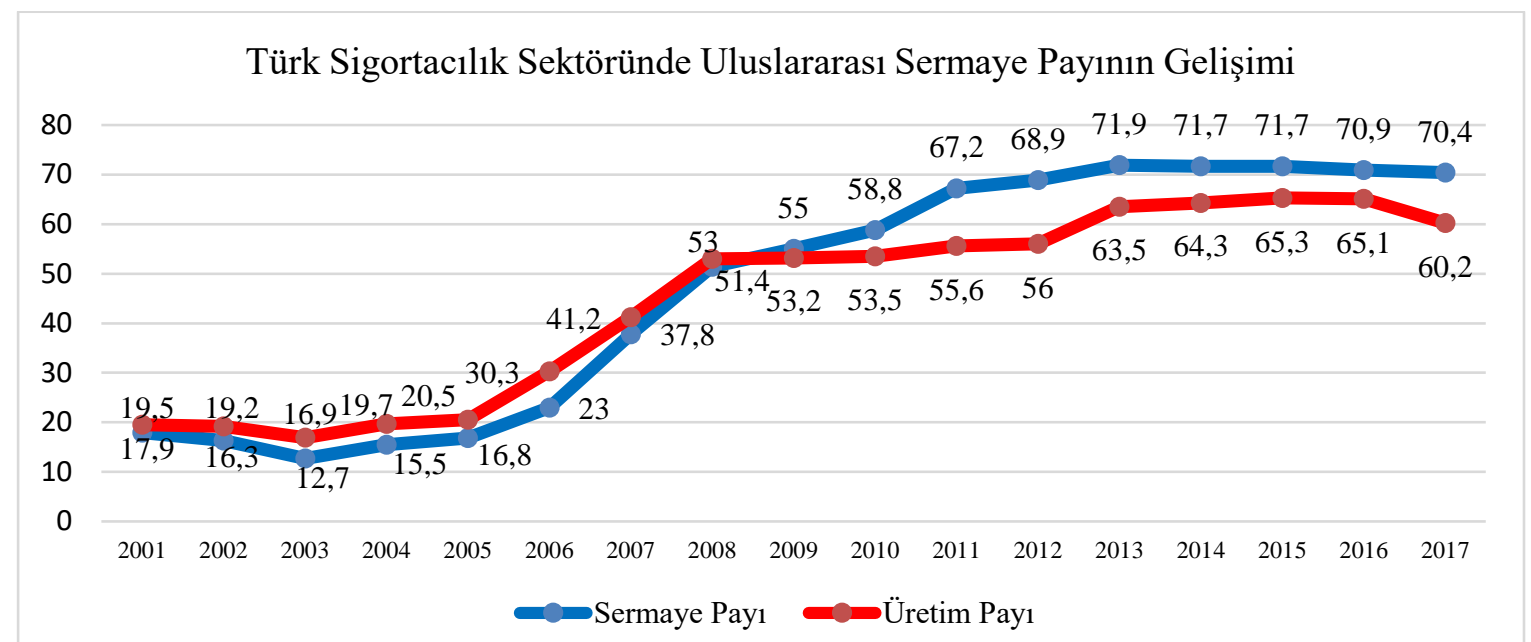

Kaynak: Maliye ve Hazine Bakanlığı Sigorta Denetleme Kurulu, Türkiye'de 2017 Y1lı Sigortacılık ve Bireysel Emeklilik Faaliyetleri Hakkında Rapor.

Sektöre yabancı sermayeli kuruluşların girişindeki yasal engellerin kaldırılmış olmasının yanında sektörün özsermaye karlılık oranının yüksek olmasıyla da açıklamak mümkündür. Şekil 4'de şirketlerin özsermaye karlılıkları gösterilmiştir. Türkiye sigorta sektörünün özsermaye karlılığı enflasyon oranlarının çok üstünde bir karlılığa sahiptir.

Şekil 4: Türkiye Sigorta Sektörü Özsermaye Karlılığ 1 (2003-2017).

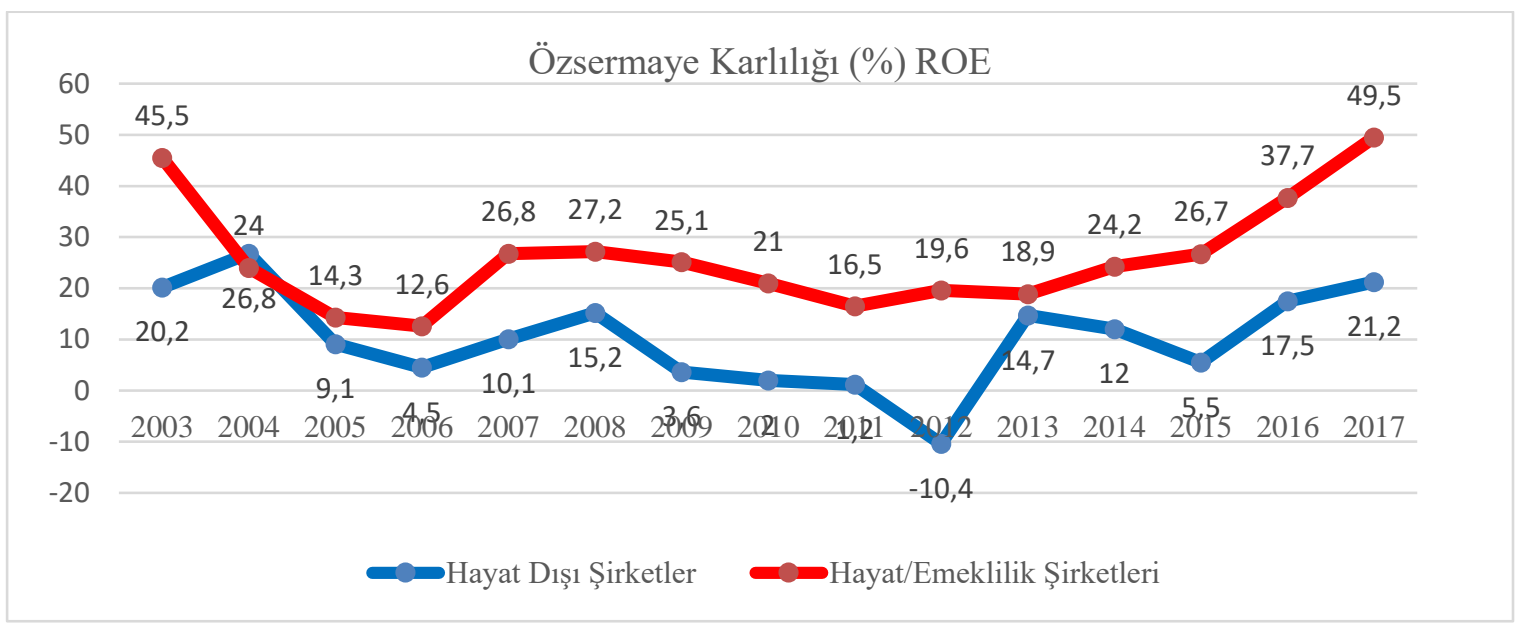

Kaynak: Maliye ve Hazine Bakanlığı Sigorta Denetleme Kurulu, Türkiye'de 2017 Yıılı Sigortacılık ve Bireysel Emeklilik Faaliyetleri Hakkında Rapor.

Küreselleşen firmalar küresel ürünler pazarlayarak belirli pazarlama faaliyetlerini standartlaştırarak maliyeti düşürebilirler. Sigortacılık sektöründe reklam filmi hazırlayan bir küresel firma aynı reklam filmini farklı dillerde seslendirerek reklam maliyetlerini düşürebilir. 
Küresel düzeyde faaliyet gösteren bir sigorta şirketi kuruluş ülkesinde küçük ve doymuş bir pazar yerine tüm dünyada yeni fursatların peşinde koşabilir. Uluslararası satışlarla gelir düzensizliklerinin de önüne geçilebilir.

İşletmelerin göz önünde bulundurması gereken bir ihtiyaç da tüm dünya insanlarının ihtiyaçlarını dikkate alarak sürdürülebilirliğin gerçekleştirilmesidir (Wild, 2017;17-18). Küresel sigortacılık faaliyetleri sigortacılık maliyetlerinin en düşük maliyet ve en yüksek kalite ile üretilmesini sağlamaktır. Bunu düşük maliyetli işgücüne erişim, düşük ve verimli teknik uzmanlığa erişim ve düşük ve kaliteli üretim girdilerine erişim imkanlarını kullanarak sağlarlar.

Türkiye'deki sigortacılık sektörünün kişi başı pirim üretiminin GSMH'ya oranı açısından değerlendirildiğinde gelişmekte olan ülkeler seviyesine gelmesi için \%100, gelişmiş olan ülkeler seviyesine gelmesi için \%400 büyüme kapasitesine sahip olduğu anlaşılmaktadır. Bu durum ekonomik krizin aşılmasını takip eden yıllarda sigortacılık sektörünün küreselleşme anlamında potansiyelinin yüksek olduğunun bir göstergesidir.

Finans alanının "bankacılık" ile birlikte en önemli sektörlerinden biri olan "sigorta sektörü", bankacılık sektörü gibi yabancı sermayenin yoğun ilgisini çekmiş ve yıllar içerisinde sektörde yabancı sermaye önemli oranda etkin ve hakim konuma gelmiştir. Türkiye'de sigorta sektörünün, uluslararası sermayenin ilgisini çekmesini başlıca nedenleri arasında; ülke iç pazarının büyüklüğü, artan ve yaşlanan nüfus, siyasi ve ekonomik istikrar, eğitim düzeyinin ve sigorta bilincinin artması, kentleşme, yasal düzenlemeler ve yüksek karlılık oranları olarak siralanabilir.

\section{METODOLOJİ}

Çalışmamızda, Türkiye Sigorta sektöründe faaliyet gösteren şirketlerin pazar payları ve mülkiyet/ortaklık yapılarındaki değişim, ve “küreselleşmenin”, Türkiye sigorta sektörüne etkisi tablo ve şekiller üzerinde analiz edilmiştir. Kullanılan verilerin kaynağı; Maliye ve Hazine Bakanlığı, Hazine Müsteşarlığı ve Türkiye Sigortalar Birliği’nin resmi istatistik ve raporlarından temin edilmiştir.

1990 yılında sigorta sektöründe yabancı yatırımcıların önündeki hukuki engellerin kaldırılması ve serbest tarife uygulamasına geçilmesi sonrası sigorta sektöründeki uluslararası sermayenin değişimi ve seyri tablo ve şekiller ile gösterilmiştir. Sigorta sektöründe şirketlerin pazar payları üzerinde küreselleşmenin etkileri iki dönem (1990-2000 ve 2001-2017) olarak ele alınmıştır. 
1990-2000 yılları arasındaki yabancı ortaklı sigorta şirketlerinin sayısı ve uluslararası sermaye payı \%50'nin üzerinde olan şirket sayıları Tablo 4'de gösterilmiştir.

Tablo 4: Türkiye Sigorta Sektöründe Yabancı Ortak Payı.

\begin{tabular}{|c|c|c|c|c|c|c|c|c|}
\hline Yıllar & $\begin{array}{c}\text { Faal Şirket } \\
\text { Sayısı }\end{array}$ & $\begin{array}{c}\text { Uluslararası } \\
\text { Ortaklı Şirket } \\
\text { Sayıs }\end{array}$ & \multicolumn{3}{|c|}{ Yabancı Ortak Payı } & & $\begin{array}{c}\text { Yabancı } \\
\text { Sermaye Payı } \\
\text { \%50> }\end{array}$ \\
\hline & & & $100 \%$ & $\% 90-100$ & $\% 50 \% 90$ & $\% 20-\% 50$ & $\% 20<$ & \\
\hline $\mathbf{1 9 9 0}$ & 46 & 22 & - & - & - & - & - & 17 \\
\hline $\mathbf{1 9 9 1}$ & 50 & 23 & - & - & - & - & - & 17 \\
\hline $\mathbf{1 9 9 2}$ & 54 & 24 & - & - & - & - & - & 15 \\
\hline $\mathbf{1 9 9 3}$ & 57 & 21 & - & - & - & - & - & 13 \\
\hline $\mathbf{1 9 9 4}$ & 55 & 20 & - & - & - & - & - & 12 \\
\hline $\mathbf{1 9 9 5}$ & 59 & 23 & - & - & - & - & - & 13 \\
\hline $\mathbf{1 9 9 6}$ & 55 & 20 & - & - & - & - & - & 11 \\
\hline $\mathbf{1 9 9 7}$ & 58 & 18 & - & - & - & - & - & 10 \\
\hline $\mathbf{1 9 9 8}$ & 62 & 18 & - & - & - & - & - & 8 \\
\hline $\mathbf{1 9 9 9}$ & 61 & 16 & - & - & - & - & - & 6 \\
\hline $\mathbf{2 0 0 0}$ & 62 & 17 & 2 & 2 & 2 & 5 & 6 & 6 \\
\hline
\end{tabular}

Kaynak: Hazine Müşteşarlığı Sigorta Denetleme Kurulu, Türkiye'de 2010 Yılı Sigortacılık ve Bireysel Emeklilik Faaliyetleri Hakkında Rapor (2010).

Küreselleşme 90’lı yıllardan 2000’li yıllara kadar daha da hız kazanmıştır.Bu döneme kadar \%100 yabancı sermayeli sigorta şirketi bulunmamakla beraber sektöre yabancı sermaye ilgisi yüksektir. 2000 yılı sonrası dönemde $\% 100$ yabancı sermayeli şirketlerin sayısı yıllar içerisinde belirgin olarak artmıştır. Tablo 9 da, 2000 yılından itibaren kesintisiz olarak 2017 yılına kadar Türkiye sigorta sektöründeki uluslararası sermayeli şirket sayıları ve ortaklık payları görülmektedir.

Tablo 5 sektördeki şirketler içerisinde uluslararası sermayeli şirketlerin artan payı görülebilmektedir. 2007 ve 2008 yıllarında sektöre ciddi oranda yabancı girişi olmuş daha sonra yataya yakın bir seyirde yabancı payı varlığını korumuştur. 2007 yılından önce \%100 sermayeli yabanc1 şirket sayısı 5 iken, 2007 yılı sonunda \%100 yabancı sermayeli şirket sayısı 11'e yükselmiştir. 2007 yılından önce uluslararası sermeye payının \%50'den fazla olduğu şirket sayısı 15 iken bu sayı 2008 sonunda \%100'ün üzerinde bir artışla 32'ye yükselmiştir. İlk defa 2008 yılsonu itibarıyla “\%50 üzerinde paya sahip yabancı ortaklı şirket” sayısı, tüm sigorta şirketlerinin \%50'sini aşarak, \%59 seviyesine yükselmiş, bu oran 2017 yılsonu itibarıyla da tüm 
sigorta şirketlerinin \%65'ine ulaşmıştır. \%100 yabancı sermayeli şirket sayısı ise 2017 yılı sonu itibarıyla 25'e yükselmiştir.

Tablo 5: Türkiye'de Uluslararası Sermayeli Şirket Sayısı ve Paylar

\begin{tabular}{|c|c|c|c|c|c|c|c|c|}
\hline \multirow[t]{2}{*}{ Yll } & \multirow{2}{*}{$\begin{array}{c}\text { Faal } \\
\text { Şirket } \\
\text { Sayısı } \\
\end{array}$} & \multirow{2}{*}{$\begin{array}{c}\text { Uluslararası } \\
\text { Ortaklı Şirket } \\
\text { Sayısı } \\
\end{array}$} & \multicolumn{5}{|c|}{ Uluslararası Ortaklık Payı } & \multirow{2}{*}{$\begin{array}{c}\text { Uluslararası } \\
\text { Sermaye Payı } \\
>\% 50\end{array}$} \\
\hline & & & $100 \%$ & $\% 90-\% 100$ & $\% 51-\% 90$ & $\% 20-\% 50$ & $<\% 20$ & \\
\hline 2000 & 62 & 17 & 2 & 2 & 2 & 5 & 6 & 6 \\
\hline 2001 & 58 & 15 & 2 & 4 & 2 & 4 & 3 & 8 \\
\hline 2002 & 52 & 14 & 2 & 4 & 2 & 3 & 3 & 8 \\
\hline 2003 & 48 & 14 & 2 & 3 & 1 & 4 & 4 & 6 \\
\hline 2004 & 47 & 16 & 2 & 3 & 2 & 4 & 5 & 7 \\
\hline 2005 & 50 & 20 & 2 & 5 & 2 & 6 & 5 & 9 \\
\hline 2006 & 51 & 24 & 5 & 4 & 6 & 8 & 1 & 15 \\
\hline 2007 & 53 & 27 & 11 & 3 & 5 & 7 & 1 & 19 \\
\hline 2008 & 54 & 39 & 15 & 10 & 7 & 6 & 1 & 32 \\
\hline 2009 & 57 & 41 & 17 & 10 & 6 & 7 & 1 & 33 \\
\hline 2010 & 58 & 43 & 20 & 13 & 3 & 6 & 1 & 36 \\
\hline 2011 & 61 & 44 & 21 & 14 & 1 & 7 & 1 & 36 \\
\hline 2012 & 63 & 43 & 21 & 13 & 1 & 7 & 1 & 35 \\
\hline 2013 & 61 & 44 & 21 & 17 & 1 & 4 & 1 & 39 \\
\hline 2014 & 63 & 44 & 23 & 14 & 2 & 4 & 1 & 39 \\
\hline 2015 & 60 & 43 & 23 & 13 & 2 & 4 & 1 & 38 \\
\hline 2016 & 61 & 45 & 25 & 13 & 2 & 3 & 2 & 40 \\
\hline 2017 & 62 & 44 & 25 & 12 & 3 & 2 & 2 & 40 \\
\hline
\end{tabular}

Kaynak: Maliye ve Hazine Bakanlığı Sigorta Denetleme Kurulu, Türkiye'de 2017 Yılı Sigortacılık ve Bireysel Emeklilik Faaliyetleri Hakkında Rapor, 2017.

2000 yılında sektörde faaliyet gösteren şirket sayısı 62, “\%50 üzerinde paya sahip yabancı ortaklı şirket" sayısı sadece 6'dır. 2017 yılı sonuna gelindiğinde sektörde faaliyet gösteren şirket sayısı yine 62 olmasına rağmen, “\%50 üzerinde paya sahip yabancı ortaklı şirket” sayısı belirgin bir artışla 25 'e yükselmiştir.

2000 yılında sektörde uluslararası ortaklı şirket sayısı 17 iken, bu sayı 2008 yılında 39'a 2017 yılında da 44'e yükselmiştir. Bir diğer önemli husus ise 2000 yılında $\% 90$ ve üzeri uluslararası ortaklı şirket sayısı 4 iken, bu sayı 2008 yılında 25'e, 2017 yılında 37'ye ulaşmıştır. Bir başka deyişle 2017 yılında; “44 uluslararası ortaklı şirketin”, 37'sindeki yabancı ortak payı \%90 ve üzerindedir. Son yıllarda artan yabancı sermaye sadece "özsermaye"de değil,aynı zamanda 
“toplam prim üretimi” itibarıyla ilk kez 2008 yılında Türk sigortacılık sektöründe \%50’nin üzerine çıkmıştır.

Şekil 5: Türkiye'de Uluslararası Ortaklı Sigorta Şirket Sayısının Seyri

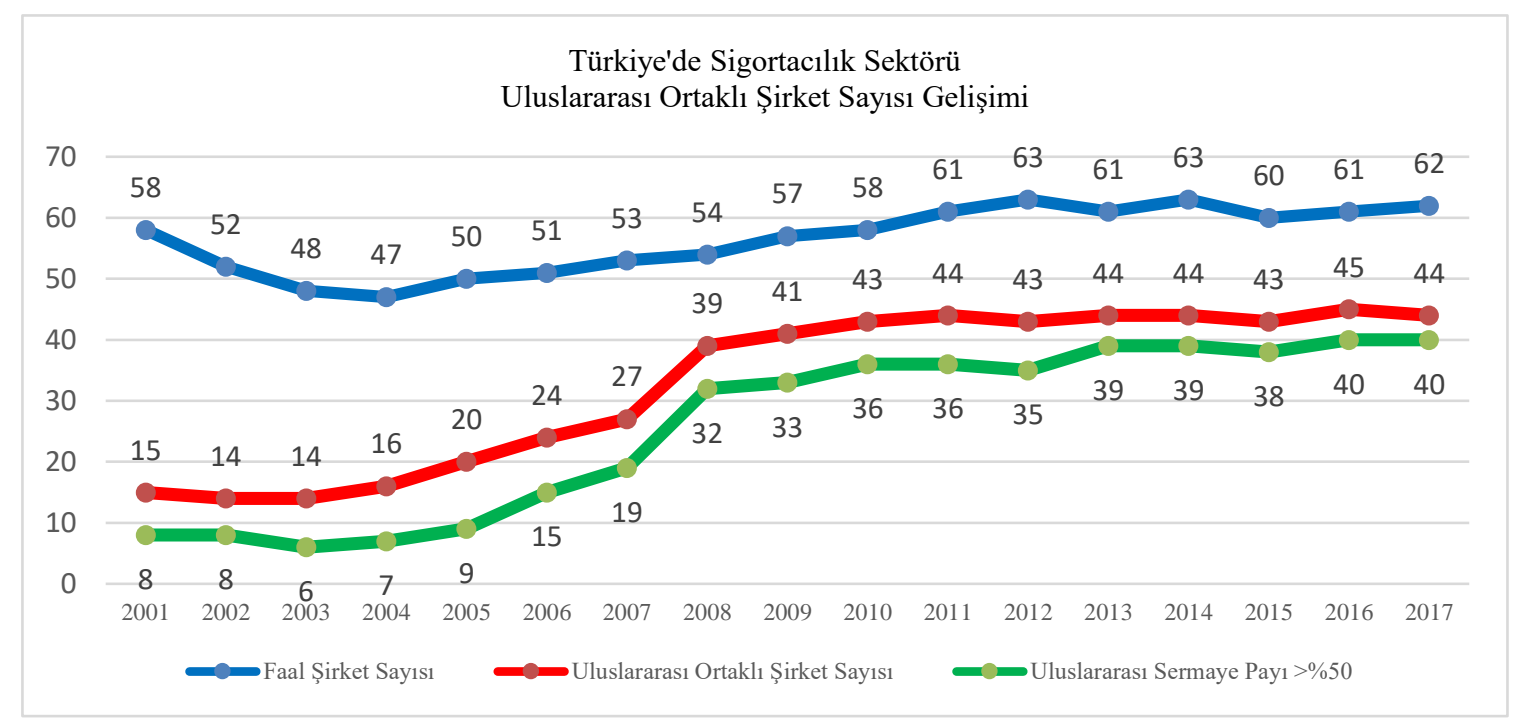

Kaynak: Maliye ve Hazine Bakanlığı Sigorta Denetleme Kurulu, Türkiye'de 2017 Yılı

Sigortacilık ve Bireysel Emeklilik Faaliyetleri Hakkında Rapor, 2017

Sigorta sektörü 2017 yılında toplam 46 milyar 556 milyon Türk Lirası prim toplamıştır. Türkiye genelinde sigorta ihtiyacı olan kurum ve bireylerin 107 trilyon Türk Lirasının üzerindeki risklerini teminat altına almıştır. Ayrıca gerçekleşen risklerin sonucunda oluşan hasar ve kayıplar için kurum ve bireylere 21 milyar 708 milyon Türk Lirası tazminat ödemesi yapmıştır. Aşağıdaki Şekil 6 ve Tablo 6'da, 2008-2017 arası 10 yıllık dönemde sektörün toplam üretim tutarları ve tazminat tutarları görülmektedir.

Şekil 6: Y1llar İtibariyle Prim Üretimi

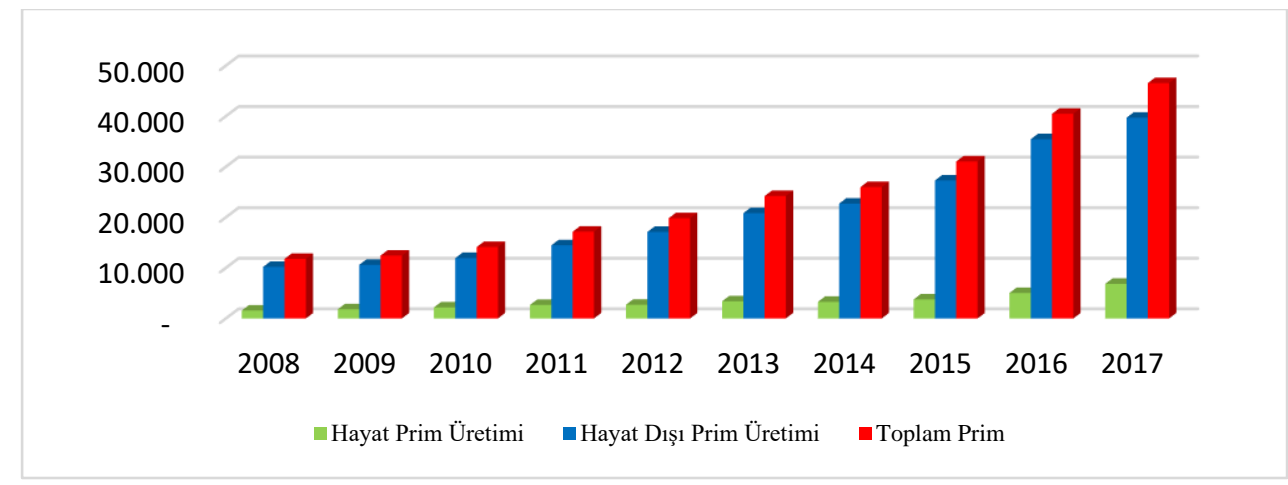

Kaynak: Maliye ve Hazine Bakanlığı Sigorta Denetleme Kurulu, Türkiye’de 2017 Yılı Sigortacılık ve Bireysel Emeklilik Faaliyetleri Hakkında Rapor, 2017. 
Tablo 6: Türkiye'de Sigortacılık Prim üretimi ile Teminat ve Tazminat tutarları (2008-2017).

\begin{tabular}{|l|r|r|r|r|r|r|r|r|r|r|}
\hline Milyon (TL) & $\mathbf{2 0 0 8}$ & $\mathbf{2 0 0 9}$ & $\mathbf{2 0 1 0}$ & $\mathbf{2 0 1 1}$ & $\mathbf{2 0 1 2}$ & $\mathbf{2 0 1 3}$ & $\mathbf{2 0 1 4}$ & $\mathbf{2 0 1 5}$ & $\mathbf{2 0 1 6}$ & $\mathbf{2 0 1 7}$ \\
\hline Prim Üretimi & & & & & & & & & & \\
\hline $\begin{array}{l}\text { Hayat D1ş1 Prim } \\
\text { Uretimi }\end{array}$ & 10.204 & 10.614 & 11.949 & 14.479 & 17.118 & 20.832 & 22.711 & 27.296 & 35.45 & 39.71 \\
\hline $\begin{array}{l}\text { Hayat Prim } \\
\text { Üretimi }\end{array}$ & 1.576 & 1.822 & 2.181 & 2.685 & 2.710 & 3.395 & 3.280 & 3.761 & 5.039 & 6.844 \\
\hline Toplam Prim & 11.780 & 12.436 & 14.130 & 17.164 & 19.828 & 24.227 & 25.991 & 31.057 & 40.48 & 46.55 \\
\hline $\begin{array}{l}\text { Hayat D1ş1 Pay } \\
\text { (\%) }\end{array}$ & 87 & 85 & 85 & 84 & 86 & 86 & 87 & 88 & 88 & 85 \\
\hline Hayat Pay1 (\%) & 13 & 15 & 15 & 16 & 14 & 14 & 13 & 12 & 12 & 15 \\
\hline Hayat Teminat1 & 224.314 & 215.594 & 259.525 & 340.612 & 387.781 & 485.712 & 564.914 & 670.80 & 746.4 & 918.2 \\
\hline $\begin{array}{l}\text { Ödenen } \\
\text { Tazminatlar }\end{array}$ & & & & & & & & & & \\
\hline $\begin{array}{l}\text { Hayat D1ş1 } \\
\text { Toplam }\end{array}$ & 5.786 & 7.087 & 7.168 & 8.305 & 9.422 & 9.756 & 11.325 & 13.853 & 15.83 & 19.20 \\
\hline Hayat Branş1 & 1.243 & 1.506 & 1.485 & 1.600 & 1.780 & 2.049 & 2.085 & 2.060 & 2.292 & 2.500 \\
\hline $\begin{array}{l}\text { Toplam } \\
\text { Oddenen } \\
\text { Tazminat }\end{array}$ & 7.029 & 8.593 & 8.653 & 9.905 & 11.202 & 11.805 & 13.410 & 15.913 & 18.12 & 21.70 \\
\hline
\end{tabular}

Kaynak: Türkiye'de Sigortacılık ve Bireysel Emeklilik Faaliyetleri Hakkında Rapor (2017, 2010 ve 2013 raporlarından derlenmiştir).

2008 y1lındaki toplam prim üretimi 11.780 milyon TL' iken, bu rakam 2017 y1lında 46.556 milyon TL'ye ulaşmıştır. Prim üretimi 10 yıllık süre zarfında yaklaşık 4 kat artarak önemli bir büyüme performansı göstermiştir. Aynı dönemde toplam ödenen tazminat tutarı yaklaşık 3 kat artarak, 7.029 milyon TL'den, 21.708 milyon TL'ye çıkmıştır. Sektörün 10 yıllık toplam prim üretimi ise; 243.658 milyon TL'dir. Bu periyottaki toplam ödenen tazminat miktarı ise; 126.342 milyon TL'dir.

Sektörün; 2013,2015 ve 2016 yıllarındaki performansı dikkat çekicidir. Özellikle 2016 yılı prim üretimi ve toplam ödenen tazminat tutarı bir arada değerlendirildiğinde sektörün son dönemdeki en parlak yılı olmuştur. 2016 yılında bir önceki yıl 25.991 milyon TL olan prim üretimi, 31.057 milyon TL'ye çıkarak yaklaşık \%20 artış göstermiştir.

2008 yılındaki toplam prim üretimi 11.780 milyon TL' iken karşılığında ödenen tazminat miktarı 7.029 milyon TL'dir. Bir başka ifadeyle hasar/prim oranı yaklaşık \%60'dır. 2017 yılında toplam prim üretimi 46.556 milyon TL'ye, ödenen tazminat ise 21.708 milyon TL'ye yükselmiştir. Hasar/Prim oranı yaklaşık \%47'dir. Süreç içerisinde şirketlerin Hasar/Prim oranları belirgin oranda azalmıştır. Bu durum, şirketlerin karlılıklarına olumlu yansımaktadır. 
Prim üretimi en yüksek ilk 20 şirketin 2017 yılı pazar payı toplamı \%78,66 olarak gerçekleşmiştir. Bir başka deyişle diğer 42 şirketin pazar payları toplamı \%21,34'de kalmıştır. İlk 20 şirket yıllar içerisinde şirket bazlı pazar payı değişimi yaşasa da, İlk 20 şirketin toplam pazar payları son beş yıl içerisinde yatay bir seyir göstermektedir.

Tablo 7 'de prim üretimi en yüksek 20 şirketin pazar payları gösterilmiştir. 2017 yılında toplam prim üretimi 46.556 milyon TL'dir. İlk 20 şirketin toplam prim üretim 36.620 milyon TL'dir. Sektördeki ilk 20 şirketin toplam prim üretimi, tüm şirketlerin toplam prim üretiminin yaklaşık \%80'ini üretmektedir. En belirgin prim üretimi artışı Allianz Sigorta A.Ş., Anadolu Anonin Türk sigorta Şirketi, Mapfre Sigorta A.Ş. ve Sompo Japan sigorta A.Ş. tarafından gerçekleştirilmiştir.

Tablo 7: Prim Üretimi En Yüksek 20 Şirketin Pazar Payları (2012-2017).

\begin{tabular}{|c|c|c|c|c|c|c|c|}
\hline & & 2017 & 2016 & 2015 & 2014 & 2013 & 2012 \\
\hline & Şirket Adı & $\begin{array}{c}\text { Pazar Payı } \\
\%\end{array}$ & $\begin{array}{c}\text { Pazar } \\
\text { Payı \% }\end{array}$ & $\begin{array}{c}\text { Pazar } \\
\text { Payı \% }\end{array}$ & $\begin{array}{c}\text { Pazar } \\
\text { Payı \% }\end{array}$ & $\begin{array}{c}\text { Pazar } \\
\text { Payı \% }\end{array}$ & $\begin{array}{c}\text { Pazar } \\
\text { Payı \% }\end{array}$ \\
\hline 1 & Allianz Sigorta AȘ & $11,03 \%$ & $14,26 \%$ & $13,06 \%$ & $12,37 \%$ & $9,32 \%$ & $8,44 \%$ \\
\hline 2 & $\begin{array}{l}\text { Anadolu Anonim } \\
\text { Türk Sigorta } \\
\text { Şirketi }\end{array}$ & $10,03 \%$ & $11,08 \%$ & $11,64 \%$ & $11,56 \%$ & $13,20 \%$ & $13,06 \%$ \\
\hline 3 & Axa Sigorta AŞ & $6,25 \%$ & $8,80 \%$ & $9,88 \%$ & $11,84 \%$ & $15,21 \%$ & $13,94 \%$ \\
\hline 4 & $\begin{array}{l}\text { Mapfre Sigorta } \\
\text { AŞ }\end{array}$ & $5,76 \%$ & $6,90 \%$ & $6,80 \%$ & $5,74 \%$ & $6,49 \%$ & $5,18 \%$ \\
\hline 5 & Aksigorta AŞ & $5,66 \%$ & $4,68 \%$ & $5,23 \%$ & $6,59 \%$ & $7,32 \%$ & $7,66 \%$ \\
\hline 6 & $\begin{array}{l}\text { Sompo Japan } \\
\text { Sigorta AŞ } \\
\end{array}$ & $4,86 \%$ & $5,52 \%$ & $3,43 \%$ & $2,64 \%$ & $2,67 \%$ & $2,63 \%$ \\
\hline 7 & Ziraat Sigorta ASS & $3,73 \%$ & $3,30 \%$ & $3,01 \%$ & $2,71 \%$ & $2,72 \%$ & $2,21 \%$ \\
\hline 8 & Güneș Sigorta AȘ & $3,57 \%$ & $3,39 \%$ & $4,15 \%$ & $4,67 \%$ & $5,17 \%$ & $5,39 \%$ \\
\hline 9 & Doga Sigorta AŞ & $3,20 \%$ & $1,98 \%$ & $0,94 \%$ & $0,10 \%$ & $0,00 \%$ & $0,00 \%$ \\
\hline 10 & Halk Sigorta AȘ & $3,18 \%$ & $2,56 \%$ & $2,44 \%$ & $2,07 \%$ & $2,26 \%$ & $2,31 \%$ \\
\hline 11 & $\begin{array}{l}\text { Ziraat Hayat ve } \\
\text { Emeklilik AŞ }\end{array}$ & $3,01 \%$ & $2,68 \%$ & $2,03 \%$ & $2,38 \%$ & $0,00 \%$ & $0,04 \%$ \\
\hline 12 & $\begin{array}{l}\text { Eureko Sigorta } \\
\text { AȘ }\end{array}$ & $2,96 \%$ & $3,05 \%$ & $3,23 \%$ & $3,08 \%$ & $3,79 \%$ & $4,00 \%$ \\
\hline 13 & $\begin{array}{l}\text { Groupama Sigorta } \\
\text { AŞ }\end{array}$ & $2,63 \%$ & $2,84 \%$ & $3,59 \%$ & $4,07 \%$ & $4,68 \%$ & $4,83 \%$ \\
\hline 14 & HDI Sigorta AȘ & $2,35 \%$ & $2,15 \%$ & $2,26 \%$ & $2,25 \%$ & $2,29 \%$ & $2,33 \%$ \\
\hline 15 & Neova Sigorta AŞ & $2,32 \%$ & $2,48 \%$ & $1,66 \%$ & $1,46 \%$ & $1,23 \%$ & $0,77 \%$ \\
\hline 16 & $\begin{array}{l}\text { Acibadem Sağlık } \\
\text { ve Hayat Sigorta } \\
\text { AȘ } \\
\end{array}$ & $1,96 \%$ & $1,83 \%$ & $1,68 \%$ & $1,60 \%$ & $1,46 \%$ & $1,36 \%$ \\
\hline 17 & Ergo Sigorta AŞ & $1,65 \%$ & $2,03 \%$ & $2,91 \%$ & $2,59 \%$ & $2,71 \%$ & $3,99 \%$ \\
\hline 18 & $\begin{array}{l}\text { Metlife Emeklilik } \\
\text { ve Hayat AŞ }\end{array}$ & $1,62 \%$ & $1,18 \%$ & $1,03 \%$ & $0,99 \%$ & $0,27 \%$ & $0,30 \%$ \\
\hline 19 & Ray Sigorta AȘ & $1,52 \%$ & $1,40 \%$ & $1,43 \%$ & $1,46 \%$ & $1,70 \%$ & $1,77 \%$ \\
\hline 20 & $\begin{array}{l}\text { Allianz Yaşam ve } \\
\text { Emeklilik AŞ }\end{array}$ & $1,35 \%$ & $1,13 \%$ & $1,42 \%$ & $1,30 \%$ & $0,03 \%$ & $0,02 \%$ \\
\hline
\end{tabular}




\section{ILLK 20 ŞiRKET \\ $\mathbf{7 8 , 6 6 \%}$ \\ $\mathbf{8 3 , 2 5 \%} \quad \mathbf{8 1 , 8 3 \%}$ \\ $81,47 \%$ \\ $\mathbf{8 2 , 5 2 \%}$

Kaynak: Maliye ve Hazine Bakanlığı Sigorta Denetleme Kurulu, Türkiye'de 2017 Yılı Sigortacılık ve Bireysel Emeklilik Faaliyetleri Hakkında Rapor, 2017.

2001 yılında ödenmiş sermayede uluslar arası sermaye payı \%17,90 iken, 2017 yılı sonunda bu oran \%70,43'e yükselmiştir. Son 17 yıllık dönemde (2001-2017) tüm sigortacılık sektöründe ödenmiş sermayede uluslararası sermayenin payı 4 kata yakın artmıştır. Aynı şekilde uluslararası sermayeli şirketlerin pazar payları 2001 yılında \%19,50 iken 2017 yılında \%60,23’e yükselmiştir. Uluslararası sermayeli şirketlerin pazar payları 3 katına yakın artırmıştır. Tablo 8 ve şekil 7'de, 2008 yılından itibaren ödenmiş sermayede ve prim üretiminde uluslararası sermayenin payı ve gelişimi görülmektedir.

Tablo 8: Prim Üretimi ve Ödenmiş Sermayede Uluslararası Sermayenin Payı.

\begin{tabular}{|c|c|c|}
\hline Yillar & $\begin{array}{l}\text { Ödenmiş Sermayede Uluslararası } \\
\text { Sermaye Payı }(\%)\end{array}$ & $\begin{array}{l}\text { Prim Üretiminde } \\
\text { Uluslararası Sermaye Payı } \\
(\%)\end{array}$ \\
\hline 2001 & 17,90 & 19,50 \\
\hline 2002 & 16,30 & 19,20 \\
\hline 2003 & 12,70 & 16,90 \\
\hline 2004 & 15,50 & 18,70 \\
\hline 2005 & 16,81 & 20,48 \\
\hline 2006 & 23,00 & 30,33 \\
\hline 2007 & 37,79 & 41,15 \\
\hline 2008 & 51,37 & 53,03 \\
\hline 2009 & 54,98 & 53,17 \\
\hline 2010 & 58,78 & 53,31 \\
\hline 2011 & 67,16 & 55,58 \\
\hline 2012 & 68,93 & 56,01 \\
\hline 2013 & 71,94 & 63,46 \\
\hline 2014 & 71,66 & 64,29 \\
\hline 2015 & 71,70 & 65,33 \\
\hline 2016 & 70,95 & 65,07 \\
\hline 2017 & 70,43 & 60,23 \\
\hline
\end{tabular}

Kaynak: Maliye ve Hazine bakanlığı/Hazine Müşteşarlığı Sigorta Denetleme Kurulu,

Türkiye'de Sigortacılık ve Bireysel Emeklilik Faaliyetleri Hakkında Rapor (2010-2013-2 
Şekil 7: Uluslararası Sermaye Payının Gelişimi (\%)

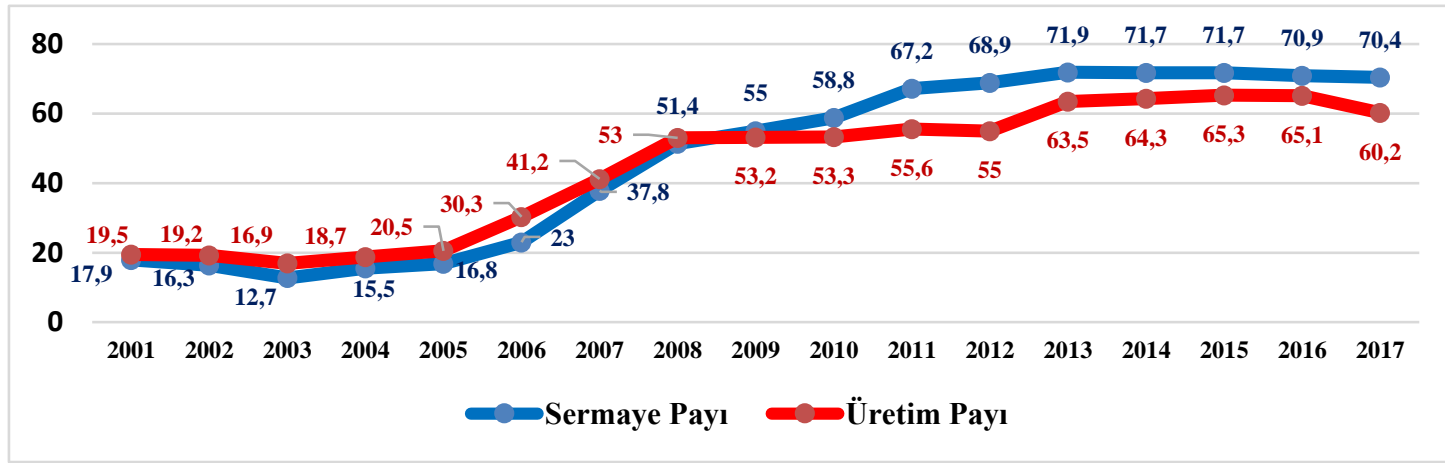

Kaynak: Maliye ve Hazine bakanlığı/Hazine Müşteşarlığı Sigorta Denetleme Kurulu, Türkiye'de Sigortacılık ve Bireysel Emeklilik Faaliyetleri Hakkında Rapor (2017).

\section{SONUÇ VE TARTIŞMA}

1990’lı yıllar globalleşmenin ivme kazandığ dönem olsa bile 2000’li yıllarda daha fazla hız kazanmıştır. 2000 yılı sonrası dönemde \%100 yabanc1 sermayeli şirketlerin sayısı yıllar içerisinde belirgin olarak artmıştır. 2000 yılında sektörde uluslararası ortaklı şirket sayısı 17 iken, bu sayı 2008 yılında 39'a 2017 yılında da 44'e yükselmiştir. Bir diğer önemli husus ise 2000 yılında \%90 ve üzeri uluslararası ortaklı şirket sayısı 4 iken, bu sayı 2008 yılında 25'e, 2017 yılında 37'ye ulaşmıştır. Bir başka deyişle 2017 yılında; “44 uluslararası ortaklı şirketin”, 37 'sindeki yabancı ortak payı $\% 90$ ve üzerindedir.

2007 ve 2008 yıllarında sektöre ciddi oranda yabancı girişi olmuş daha sonra yataya yakın bir seyirde yabancı payı varlığını korumuştur. İlk defa 2008 yılsonu itibarıyla“\%50 üzerinde paya sahip yabancı ortaklı şirket” sayısı, tüm sigorta şirketlerinin \%50'sini aşarak, \%59 seviyesine yükselmiş, bu oran 2017 yılsonu itibarıyla da tüm sigorta şirketlerinin \%65'ine ulaşmıştır. \%100 yabancı sermayeli şirket sayısı ise 2017 yılı sonu itibarıyla 25'e yükselmiştir.

Sigorta sektöründe şirketlerin prim üretiminden aldıkları paylar, sigortacılık sektörü açısından son derece önemlidir. Prim üretimi, şirketlerin pazar payları için iyi bir ölçü teşkil ettiği gibi aynı zamanda karı ve karlılığı doğrudan etkilemektedir. Pazar payı ve prim üretiminin asıl önemli yanı fon elde edilebilmesine olanak sağlamasıdır. Biriken fonların etkin kullanımı ve fon yönetimi ile büyük karlar elde edilebilmektedir. Türkiye sigorta sektöründe prim üretimi son 10 yıllık süre zarfında yaklaşık 4 kat artarak önemli bir büyüme performansı göstermiştir. Aynı dönemde toplam ödenen tazminat tutarı yaklaşık 3 kat artarak prim üretiminin gerisinde kalmıştır. 
2001 yılında ödenmiş sermayede uluslararası sermaye payı \%17,90 iken, 2017 yılı sonunda bu oran \%70,43'e yükselmiştir. Son 17 y1llık dönemde(2001-2017) tüm sigortacılık sektöründe ödenmiş sermayede uluslararası sermayenin payı 4 kata yakın artmıştır. Aynı şekilde uluslararası sermayeli şirketlerin pazar payları 2001 yılında \%19,50 iken 2017 y1lında \%60,23'e yükselmiştir. Uluslararası sermayeli şirketlerin pazar payları 3 katına yakın artırmıştır. Ödenmiş sermayede de prim üretiminde de uluslararası sermayeli şirketlerin hakimiyetleri mevcuttur. Prim üretim ve pazar payında ilk 5 şirket içerisinde \%100 yerli sermayeli tek şirket Anadolu Anonim Türk Sigorta Şirketi'dir.

Türkiye'deki sigortacılık sektörünün kişi başı pirim üretiminin GSMH'ya oranı açısından değerlendirildiğinde gelişmekte olan ülkeler seviyesine gelmesi için \%100, gelişmiş olan ülkeler seviyesine gelmesi için \%400 büyüme kapasitesine sahip olduğu anlaşılmaktadır. Bu durum ekonomik krizin aşılmasını takip eden yıllarda sigortacılık sektörünün küreselleşme anlamında potansiyelinin yüksek olduğunun bir göstergesidir.

Sigorta sektörü 2017 yılında toplam 46 milyar 556 milyon Türk Lirası prim toplamıştır. Gerçekleşen risklerin sonucunda oluşan hasar ve kayıplar için kurum ve bireylere 21 milyar 708 milyon Türk Lirası tazminat ödemesi yapmıştır. Sektörün özsermaye karlılık oranı oldukça yüksektir.

Finans alanının "bankacılık" ile birlikte en önemli sektörlerinden biri olan "sigorta sektörü", bankacılık sektörü gibi yabancı sermayenin yoğun ilgisini çekmiş ve yıllar içerisinde sektörde yabanc1 sermaye önemli oranda etkin ve hakim konuma gelmiştir. Türkiye'de sigorta sektörünün, uluslararası sermayenin ilgisini çekmesini başlıca nedenleri arasında; Türkiye sigorta sektörünün özsermaye karlılığı enflasyon oranlarının çok üstünde bir karlılığa sahip olması, ülke iç pazarının büyüklüğü, artan ve yaşlanan nüfus, siyasi ve ekonomik istikrar, eğitim düzeyinin ve sigorta bilincinin artması, kentleşme, yasal düzenlemeler ve yüksek karlılık oranları olarak sıralanabilir.

Uluslararası şirketler, Türk sigorta şirketlerini satın alarak veya ortak olarak, sektöre hızla nüfuz etmektedir. Ödenmiş sermaye ve prim üretiminde uluslararası sermayenin payı oldukça yüksek bir noktaya ulaşmıştır. Sigorta sektörü hızla dışa bağımlı hale gelmektedir. Önümüzdeki süreçte sektörde şirket sayısında konsolidasyon ve küçük şirketlerin büyükler tarafından satın alınması ve orta-uzun vadede sektörde faaliyet gösteren yerli ve milli şirketlerimizin bu rekabette geride 
ve devre dışı kalacağı beklenmelidir. Yabancı sermayeli işletmelerin doğasında aşırı kazanma arzusu vardır ve "yüksek kâr odaklı" hizmet sunumu söz konusudur. Türkiye sigorta sektöründe oluşabilecek tekelci piyasanın, ileri dönemde yüksek tüketici fiyatlarına sebebiyet vermesi muhtemeldir. Hazine ve Maliye Bakanlığı ve Ticaret Bakanlığı'nın bu noktada kontrolü elinde tuttuğunu söylemek mümkün değildir.

Sigorta sektörünün ekonomik işlevsellik anlamında en önemli yanı fon yaratma kapasitesidir. Türkiye sigorta sektörü prim üretimi 45 milyar TL'nin üzerindedir. Yabancı sigorta şirketleri elde ettikleri kazancı ve topladıkları fonları ülke dışına çıkartılarak transfer edilmesi önemli derecede dış ticaret açığına sebep olabilmektedir. Finans kesiminin imtiyazlı olan alanlarından banka ve sigortacılık sektöründe yerlilik oranı aranması, oluşan fonların ülke dışına çıkarılmasına yüksek vergi konulması veya elde edilen karların belli oranının üstünün şirketler yerine bir fonda toplanması bir çözüm olabilir. Bu alanda milli bir politika gerekliliği şarttır. Bu alanın önündeki en az 4 kat büyüme potansiyeli düşünülerek bu imtiyazlı alanın yeniden düzenlenmesi yerinde olacaktır.

\section{KAYNAKÇA}

Akpınar, Ö.(2016). Sigorta sektöründe pazarlama süreci: Acentelerin rolü ve önemi. Turkish Journal Park Academic, sayı 45, s.55

Aktan, C. C. ve İstiklal Y. V. "Globalleşme Sürecinde Çok Uluslu Şirketler", http://www.canaktan.org/ekonomi/cok-uluslu/aktan-makale.pdf (Erişim Tarihi: 24.12.2018)

Aktan, Çoşgun ve Vural, İsmail Y., (2018), Globalleşme sürecinde çok uluslu şirketler (https://docplayer.biz.tr/48395-Globallesme-surecinde-cokuluslu-sirketler-coskun-canaktan-istiklal-y-vural.html) (Erişim 25.12.2018)

Alayoğlu, N. (2010). Rekabet üstünlüğü sağlamada insan kaynakları ve rekabet stratejileri uyumunun önemi. s.28

Altıer, S., (2007), "Yabancı Yatırım Sermayesi Ülkemizde Neden Sanayiye Gitmiyor?", 21. Yüzyıl Türkiye Enstitüsü, 28 Mayıs 2007 (http://www.21yyte.org/tr).

Barış, S.,\& Barış, A. (2018, April). Küreselleşme ve Ekonomik Büyüme İlişkisi: Avrupa Birliği Ülkelerinden Deliller. In Proceedings of 4 th SCF International Conference on "Economics and Social Impacts of Globalization" and "Future Turkey-European Union Relations" (p. 63).

Çekici, M. E. Ve İnel, M. N.,(2013), Türk Sigorta sektörün Direkt Prim Üretimlerinin tahmin Teknikleri İle İncelenmesi, Marmara Üniversitesi İIBBF Dergisi, 34, 135-

Çiftçi, H. (2004). Türk sigorta sektörünün sorunları; DEA analizi ile şirketlerin etkinlik düzeylerinin belirlenmesi. s.134-135 Sosyal Bilimler Enstitüsü Dergisi, 2004 
Daft, R. L., Murphy, J., \&Willmott, H. (2010). Organization the oryanddesign. Cengage learning EMEA.

Demir, D.,\& Altıntaş, H. (2018, April). Küreselleşme, Doğrudan Yabancı Yatırımlar ve Gelir Eşitsizliği Arasındaki İlişki: Dinamik Panel Veri Yaklaşımı. In Proceedings of 4 th SCF International Conference on "Economics and SocialImpacts of Globalization" and "Future Turkey-European Union Relations" (s. 99).

Dinçer, Ö. (2003). Stratejik Yönetim ve İşletme Politikası, İstanbul: Beta Basım,7.Bask1 s.95, s. 235

Dursun, T. ve Gürsev, S. (2016). Pazarlamada Dağıtım Kanalları Yönetimi ve Lojistik Merkezlerin Gelişiminde Kümeleme Yaklaşımı, Marmara Üniversitesi Öneri Dergisi, Cilt 12, Say1 45, İstanbul, 555-568.

Elçin, A. B. (2012). Küreselleşmenin Tarihçesi. Küreselleşmenin Tarihçesi. Ankara.

Ellwood, W. (2002). Küreselleşmeyi Anlama Kılavuzu. İstanbul: Metis Yayınları.

Encyclopedia of 1848 Revolutions. Zollverein, Ohio University, 2018, <https://www.ohio.edu/chastain/rz/zollvrn.htm>, (17.12.2018). Free Pres, London, s.54.

Gaston Noel ve Ahmed M. Khalid. (2010). Globalization and Economic Integration, Edward Elgar,UK, , s. 3.

Georgantzas, N. C.,Katsamakas, E., Solowiej, D., Ford, A., Ford, D. N., \&Anderson, G. E. (2009). Giddens' globalization: Exploring dynamic implications. In Proceedings of the 27th System Dynamics Society International Conference (s. 26-30).

Gövdere, B. (2009) “Türkiye’de hizmetler sektöründe doğrudan yabancı yatırımlar”, Süleyman Demirel Üniversitesi İktisadi ve idari Bilimler Fakültesi Dergisi Y.2009, C.14, S.1 s.5368.

http://www.kof.ethz.ch

http://www.sigortagundem.com/haber/generali-sigorta-ve-remax-turkiyeden/1040933

https://tr.wikipedia.org/wiki/Âdem

https://tusiad.org/tr/yayinlar/raporlar/item/9903-2018-yilina-girerken-turkiye-ve-dunyaekonomisi

https://www.aksigorta.com.tr/yatirimci-iliskileri/faaliyet-raporlari

https://www.allianz.com.tr/tr_TR/faaliyetlerimiz/bizden-haberler.html

https://www.allianzsigorta.com.tr/tr/hakkimizda/bilgilendirme-ve-raporlar/ana raporlar/finansal-bilgiler-ve-faaliyet-raporlari/

https://www.anadolusigorta.com.tr/tr/yatirimci-iliskileri/finansal-bilgiler/faaliyet-raporlari https://www.axasigorta.com.tr/axa-bkm-isbirligi-ile-islemler-artik-daha-guvenli https://www.axasigorta.com.tr/finansal-bilgiler.aspx?pageID=35

https://www.bloomberght.com/emtia/brent-petrol 
https://www.ethz.ch/content/dam/ethz/specialinterest/dual/kofdam/documents/Globalization/2 018/Globalisationindex2017.zip

https://www.hazine.gov.tr/sigortacilik-ve-ozel-emeklilik-raporlari

https://www.kap.org.tr/tr/bist-sirketler

https://www.kof.ethz.ch/en/forecasts-and-indicators/indicators/kof-globalisation-index.htm

https://www.mapfre.com.tr/sigorta-tr/biz-kimiz/bilgi-toplumu-hizmetleri/malibilgiler/faaliyet-raporlari/

https://www.resmiistatistik.gov.tr/?q=tr/content/gsyh-büyümehttps://www.tcmb.gov.tr/kurlar/kurlar_tr.html

https://www.sompojapan.com.tr/tr/kurumsal/hakkimizda/finansal-bilgiler/faaliyet-raporlari https://www.statista.com/chart/3882/the-worlds-most-globalised-countrie/ https://www.tobb.org.tr/Documents/yayinlar/2018/EkonomikRapor2017.pdf

https://www.tsb.org.tr/bilancolar.aspx?pageID=910

https://www.tsb.org.tr/gelir-tablosu.aspx?pageID=911

https://www.tsb.org.tr/resmi-istatistikler.aspx?pageID=909

https://www.tsb.org.tr/sigortanin-tarihi.aspx?pageID=438

İncekara, A.,\& Savrul, A. G. M. (2011). Küreselleşme, Büyüme Ve Ekonomik Entegrasyonlar: Türkiye Açısından Bir Değerlendirme. İstanbul Üniversitesi İktisat Fakültesi Mecmuasi, 61(2), s.5.

Kamilçelebi ve Okur, (2010). "Rekabet Üstünlügünün Sürdürülebilirliği İçin Yeni Yönetim Tekniklerinin Önemi ve Seçilmiş Sigorta Şirketleri Üzerine Bir Araştırma”. TSEV Sigorta Araştırmaları Dergisi, S: 7. 2010

Kamilçelebi, H. (2012). “Osmanlı Devleti’nde Sigortacılığa Yönelik Dini Yaklaşım”. Ekonomi Bilimleri Dergisi, Cilt 4, No 1, 2012 s. 105-114

Kanıbir, H.(2004). "Yeni Bir Rekabet Gücü Kaynağı Olarak Entelektüel Sermaye ve Organizasyonel Performansa Yansimaları, Journal of Aeron auticsand Space Technologies, 2004 s.26.

Karabıçak, M. (2002). Küreselleşme Sürecinde Gelişmekte Olan Ülke Ekonomilerinde Ortaya Çıkan Yönelim ve Tepkiler. Süleyman Demirel Üniversitesi İktisadi ve İdari Bilimler Fakültesi Dergisi, 7(1).

Karpat, Kemal H.,(2006). “Osmanlı'da Değişim, Modernleşme ve Uluslaşma”. Çev. Dilek Özdemir, Ankara, İmge Yayınları, 2006.

Keller, M. P. (2000). "Pension Reform, Private Saving, and the current account in a

Kesici, A.,\& Tunç, N. F. (2018). Investigating the digital addiction level of theuniversitystudentsaccordingtotheirpurposesforusingdigitaltools. Universal Journal of Educational Research, 6(2), 235-241.

Kilıçkaplan, S. Ve Karpat, G.(2004). "Türkiye hayat sigortası sektöründe etkinliğin incelenmesi.”. D.E.Ü.İ.İ.B.F. Dergisi Cilt:19 Sayı:1, Y1l:2004, ss:1-14s.2 
Kohen, D. (2009). Mal Canın Yongasıdır, İstanbul, Osmanlı Bankası Araştırma Merkezi Yayınları, 2009.

McLuhan, M. (1962). The Gutenberg galaxy.

Mill, A. (2017). Ekonomi 101 - Arz-Talep Dengesi ve Ekonomik Büyümeden Döviz Kurları ve Bankacılığa Kadar Ekonomi Hakkında Bilmeniz Gereken Her Şey. (N. Soysal, Çev.) İstanbul: Say Yayınları.

Ömürbek, N. ve Altın, F.G.(2008) "Sigorta sektöründe bilgi teknolojilerinin uygulanmasına yönelik bir araştırma" Süleyman Demirel Üniversitesi İktisadi ve İdari Bilimler Fakültesi Dergisi Y.2008, C.13, S.3 s.105-127.

Öymen, Onur, (2000), Geleceği Yakalamak, Remzi Kitapevi, İstanbul. s.26-27

Özcan, C. C., Özmen, İ., \& ÖZCAN, G. (2018). Ticari Dışa Açıklığın Ekonomik Büyüme’ye Etkisi: Yükselen Piyasa Ekonomileri. Selçuk Üniversitesi Sosyal Bilimler Enstitüsü Dergisi, (40), 60-73.

Porter,M.(1985). Competitive Advantage: Creating and Sustaining Superior Performance, s.54

Schiff, Maurice ve L. Alan Winters, (2003) Regional Integration and Development, Worldbank and Oxford, Washington, s. 6-10.

Sigma Dergisi 2017, Dünya Sigortacılığı No:3/2018

Sigortacılık Ve Bireysel Emeklilik Faaliyetleri Hakkında Rapor 2017, Hazine ve Maliye Bakanlığı, Sigorta Denetleme Kurulu

Small Open Economy IMF WP /00 /171/October 2000, JEL Classification numbers: HSS,E13,E20)

Sürmeli, Hüsniye ve Yükselen, Cemal, (2000): “İhracatçı İşletmelerin Dış Pazarlamada Rekabet Üstünlüğü Faktörleri, Tekstil ve Hazır Giyim Sektörü Üzerine Bir Araştırma”, Yönetim Dergisi, Say1.36, S.69-78

Şenel, .A., (2007). "Sigorta Sektörü Fon Yaratma Kapasitesi ve Sermaye Piyasasına Etkisi: Türkiye'deki Durum, Doktora tezi, C.Ü. Sosyal Bilimler Enstitüsü, Sivas.

Şit, Mustafa, \& Şit, Ahmet, (2013). Türkiye'de Doğrudan Yabancı Sermayenin Sektörel: Hizmet Sektörü Üzerine Bir Değerlendirme. Sosyal Bilimler Dergisi, 3(5), 36-54.

Talas, M.,\& Bildirici, S.S. (2008) Farklı Yönleriyle Küreselleşme. İstanbul, Doğu Kütüphanesi.

Tora ve Aftara (2002), Bereşit, 1,1, Türkiye Hahambaşılı̆̆1, s.69

Tunay, N.(2015) "Sigorta Sektöründe Aracılar Arası Rekabet ve Bileşenleri: Yeni Yönelimler Işığında Türkiye İçin Çıkarsamalar”. s.66-s.69

Türedi, S. (2016). Küreselleşmenin Ekonomik Büyüme Üzerindeki Etkisi: Gelişmekte Olan Ülkeler İçin Panel Veri Analizi, International Osmaneli Social Sciences Congress, Korkuteli, 12-13-14 October 2016.

Uras, T. G.(1979). Türkiye'de Yabancı Sermaye Yatırımları, İstanbul, Formül Matbaası.

Wild. John J., Wild. Kenneth L., (2017). Uluslararası İşletmecilik Küreselleşmenin Zorlukları, Nobel Yayınlar1, 8. Bask1,) 
Yücemiş, B. T., Akpınar, Ö., \& Okay, G. (2011). Türk Sigorta Sektöründe Yabancı Payının Sektöre Olası Etkileri: AB Perspektifinde Değerlendirilmesi. Avrupa Araştırmaları Dergisi, 19(1), 53-75.

Yücemiş, B.T.,Akpınar, Ö. ve Okay, G.(2011)." Türk sigorta sektöründe yabancı payının sektöre olası etkileri: AB perspektifinde değerlendirilmesi”. Avrupa Araştırmaları dergisi Cilt 19, Say1:1., 53-75. 